\title{
Tabularia
}

\section{Poetry, punctuation and performance: Was there an aural context for Dudo of Saint-Quentin's}

\section{Historia Normannorum?}

Poésie, ponctuation et performance : dans quelle mesure peut-on parler d'un contexte oral pour l'Historia Normannorum de Dudon de Saint-Quentin? Poesia, punteggiatura e performance : in che misura è possibile parlare di un contesto orale per l'Historia Normannorum di Dudone di Saint-Quentin?

\section{Benjamin Pohl}

\section{OpenEdition}

\section{Journals}

\section{Electronic version}

URL: http://journals.openedition.org/tabularia/2781

DOI: 10.4000/tabularia.2781

ISSN: $1630-7364$

Publisher:

CRAHAM - Centre Michel de Boüard, Presses universitaires de Caen

\section{Electronic reference}

Benjamin Pohl, « Poetry, punctuation and performance: Was there an aural context for Dudo of SaintQuentin's Historia Normannorum?», Tabularia [Online], Autour de Serlon de Bayeux : la poésie normande aux XIe-XIIe siècles, Online since 28 September 2016, connection on 01 May 2019. URL : http:// journals.openedition.org/tabularia/2781 ; DOI : 10.4000/tabularia.2781 


\title{
Poetry, punctuation and performance: Was there an aural context for Dudo of Saint-Quentin's Historia Normannorum? ${ }^{1}$
}

Poésie, ponctuation et performance: dans quelle mesure peut-on parler d'un contexte oral pour l'Historia Normannorum de Dudon de Saint-Quentin?

\section{Poesia, punteggiatura e performance: in che misura è possibile parlare di un contesto orale per l'Historia Normannorum di Dudone di Saint-Quentin?}

\author{
Benjamin POHL \\ University of Bristol \\ benjamin.pohl@bristol.ac.uk
}

\begin{abstract}
:
This article explores the possibility of an aural and/or performative context for the reception and dissemination of Dudo of Saint-Quentin's Historia Normannorum. Scholarship to date has produced two main schools of thought concerning the Historia Normannorum's target audiences during the eleventh and twelfth centuries, one of which discusses Dudo's work in the capacity of a Latin school book, thereby emphasising its didactic and educational purpose, whereas the other identifies the main circles of reception at the courts of the Norman dukes and their peers, thus stressing the text's potential for dynastic self-fashioning, ritual and display. Drawing on the primary evidence of the surviving eleventh- and twelfth-century manuscripts, and combining it with recent theoretical work concerning the different modes of literary communication, this article argues that these schools of thoughts are not mutually exclusive. Based on a detailed study
\end{abstract}

1. The initial work on this article was carried out in 2014 with support from the German Academic Exchange Service (DAAD) and the Neil Ker Memorial Fund (British Academy). It was completed with support from the Alexander von Humboldt Foundation, the Research Foundation Flanders (FWO) and the University of Bristol. I am extremely grateful to Teresa Webber, Michael Gullick and Liesbeth van Houts for commenting on an early draft version, as well as to the journal's anonymous peer-reviewers, whose helpful suggestions improved my argument significantly. Any remaining mistakes are entirely mine, of course. Moreover, I would like to thank Felice Lifshitz, who in reviewing my monograph on the Historia Normannorum has emphasised the desideratum of producing a study that explores the topic of performance and aurality in greater detail. I hope that this article will be able to do just that. 
of the manuscripts' punctuation and mise-en-page (including their use of colour), the article showcases the Historia Normannorum as a "multimedia text" that rather naturally lent itself to being read and/or performed in an aural setting. Conceptualising Norman literature and historiography in such a way significantly enriches and transforms our understanding of literary and poetic culture in the Norman and Anglo-Norman worlds.

Keywords: Dudo of Saint-Quentin, Normandy, historiography, poetry, manuscripts, literacy, aurality, Latin, performance, audience

Résumé:

Cet article examine la possibilité d'un contexte oral et / ou performatif pour la réception et la diffusion de l'Historia Normannorum de Dudon de Saint-Quentin. À ce jour, l'érudition se partage en deux courants de pensée concernant le public visé aux XI ${ }^{e}-X I I^{e}$ siècles, l'un considérant l'œuvre de Dudon comme un livre d'école en latin, en s'appuyant sur son objectif didactique et éducatif, l'autre s'attachant à identifier les principaux cercles de réception de l'ouvre à la cour des ducs normands et de leurs pairs, en mettant l'accent sur le pouvoir $d u$ texte à promouvoir la dynastie et ses rituels. En croisant les manuscrits des XI et $X I I^{e}$ siècles et les récents travaux théoriques sur les modes littéraires de communication, l'article démontre que ces écoles de pensée ne sont pas exclusives l'une de l'autre. Fondé sur une étude détaillée de la ponctuation et de la mise en page (ainsi que sur l'usage de la couleur), l'article présente l'Historia Normannorum comme un texte multimédia qui se prêtait à la lecture et/ou était performatif dans un cadre oral. Concevoir la production documentaire normande et l'historiographie de cette manière enrichit et transforme de manière significative notre compréhension de la culture littéraire et poétique des mondes normands et anglo-normands.

Mots-clés: Dudon de Saint-Quentin, Normandie, historiographie, poésie, manuscrits, littératie, oralité, latin, performance, auditoire

Riassunto ${ }^{2}$ :

Questo articolo prende in esame la possibilità dell'esistenza di un contesto orale e / o esecutivo per la ricezione e la diffusione dell'Historia Normannorum di Dudone di Saint-Quentin. Ad oggi, l'erudizione si divide in due correnti di pensiero relative al tipo di pubblico interessato dall'opera nei secoli XI e XII: l'una considera l'opera di Dudone come un libro scolastico in latino, basandosi sulle sue finalità didattiche ed educative; l'altra si sofferma sull'identificazione delle principali cerchie di ricezione dell'opera presso la corte dei duchi normanni e dei loro pari, mettendo l'accento sul valore del testo ai fini della promozione della dinastia e dei suoi rituali. Mettendo in relazione tra loro i manoscritti di XI e XII secolo e i recenti lavori teorici sulle modalità della comunicazione letteraria, l'articolo dimostra che una scuola di pensiero non esclude l'altra. Fondato su uno studio dettagliato della punteggiatura e dell'impaginazione (cosi come sull'uso dei colori), l'articolo presenta l'Historia Normannorum come un testo multimediale che si prestava alla lettura e/o era eseguito in un contesto d'oralità. Concepire in questo modo la produzione documentaria normanna e la storiografia arricchisce e trasforma in maniera significativa la nostra comprensione della cultura letteraria e poetica dei mondi normanno ed anglo-normanni.

Parole chiave: Dudone di Saint-Quentin, Normandia, storiografia, poesia, manoscritti, alfabetizzazione, oralità, latino, performance, pubblico

2. Translation by Laura VANGONE, Centre de Recherches Archéologiques et Historiques Anciennes et Médiévales, Normandie Univ, UNICAEN, CNRS, CRAHAM, 14000 Caen, France. 
Around the turn of the first millennium, Dudo of Saint-Quentin wrote the first dynastic history of Normandy and its ruling family. Having benefited from an education that was deeply rooted in the literary and historical traditions of the late Carolingian Empire, Dudo composed his Historia Normannorum (hereafter $H N$ ) in refined Latin prose interspersed with elegant pieces of poetry - a sophisticated style of composition known to scholars as the prosimetrum ${ }^{3}$. More than ninety poems can be counted throughout the text, and these are written in over thirty different poetic metres ${ }^{4}$. The prosimetrum formed part of the Middle Ages' literary inheritance from late Antiquity, having been celebrated in the works of Boethius and Martianus Capella, but it was no longer common currency in early eleventh-century Europe, least of all in the provinces that used to make up West Francia ${ }^{5}$. However, there is evidence to suggest that a new literary and poetic scene emerged at Rouen under the rule of Dukes Richard I (942-96) and Richard II (996-1026) ${ }^{6}$. Rouen's reputation for literature and learning soon radiated outwards, attracting both native and foreign writers who embraced this classical revival ${ }^{7}$. Whilst expediting the communication and cross-fertilisation between different literary traditions - poetry and prose, secular and ecclesiastical, Latin and vernacular -, this flourishing literary milieu around the Norman ducal court is not known, however, to have generated any other work as firmly rooted in the prosimetric tradition as Dudo's. When the HN was published in 1015 (or soon afterwards) under the commission of Duke Richard II, it was received as something of a novelty item that combined innovative style with contents that adhered firmly to the existing traditions of historical and political thought ${ }^{8}$. It is no surprise, therefore, to find that scholars have explored the $H N$ from a wide range of perspectives, ranging from intricate textual and linguistic analyses to investigations concerning the work's use (or abuse) by later generations of chroniclers, most prominently perhaps the eleventh-century monk-historian, William of Jumièges, and his two twelfth-century continuators, Orderic Vitalis and Robert of Torigni ${ }^{9}$. Dudo's extraordinary (if somewhat eclectic) literary repertoire is an

3. Contrary to the arguments made in previous scholarship (particularly Huisman, 1984), more recent work on the $H N$ 's manuscript tradition has revealed that the poems actually formed an integral feature of the text's original plan of composition, rather than a later addition (or so-called "prose redaction"); see PoHL, 2013; PoHL, 2015, p. 84-108.

4. These poetic metres have been identified in HN, transl. Christiansen, p. 236-237. Christiansen counts a total of 89 poems (ibid., p. 249), whereas my own analysis reveals a total of 91 (see Appendix 1). For a schematic overview of the poems and their metres, see appendices 3-5 in POHL, 2015, p. 264-272.

5. BARtoňKová, 1976; Polheim, 1963. On the prosimetrum and its place amongst different medieval literary genres, see PABST, 1994; Dronke, 1994; ZiolkowsKi, 1997; SCHALlER, 1998. Dudo's use of the prosimetrum has been explored in greater detail by PABST, 1995.

6. See the case study of Norman Latin poetry and its institutionalisation by ZIOLKOWSKI, 1989, p. 39-41.

7. McDonough, 1995; VAn Houts, 2013; Pohl, 2015, p. 216-221.

8. Pohl, 2012; PонL, 2015, p. 109-155, 156-223. Also cf. SHоркоw, 1989; Sноркоw, 1997; VopeliusHOLTZENDORFF, 1969.

9. Plassmann, 1995; van Houts, 1980; Pohl, 2012. 
area that has attracted particular attention, and thanks to the efforts of Karsten Friis-Jensen, Pierre Bouet and others, important parallels have been established between the $H N$ and the works of great Latin writers such as Virgil and, writing one and a half centuries after Dudo, the Danish historian Saxo Grammaticus ${ }^{10}$.

With regard to the $H N$ 's function, two main lines of argument can be distinguished in scholarship to date: the first primarily discusses Dudo's work in the capacity of a Latin school book, thereby emphasising its didactic and educational purpose ${ }^{11}$. According to this interpretation, Dudo's original design for the poems (and the prosimetric nature of the text as a whole) was guided by his intention (or the wish of his patrons) to produce some kind of poetic primer or style guide aimed at teachers and/or students of Medieval Latin. Advocates of this line of thought have identified the HN's target audiences and primary circles of reception in the context of Normandy's academies and the Frankish grammar schools ${ }^{12}$. Within such an environment, the ideal reader would have been "not just anybody capable of reading Latin, but someone who had followed, or was following, the full curriculum of the seven liberal arts" ${ }^{13}$, therefore making Dudo's panegyric history of Richard I and his ancestors "ideally suited to imbue the schoolboys with loyalty to the exalted lineage of their virtuous dukes" 14 , at the same time as educating them grammatically. Whilst some have embraced this theory, others - myself included - have located the HN's primary audience(s) at the ducal, comital and royal courts of Richard II and his peers, including King Robert II the Pious ${ }^{15}$. Having originated in the scholarship of the 1960s-1980s, this theory was recently rehabilitated due to the reconstruction of a full programme of illumination on the basis of one of the HN's later eleventh-century manuscripts, Rouen, Bibliothèque Municipale, ms 1173/ $\mathrm{Y}_{11}$ (hereafter $\left.\mathrm{ms} \mathrm{R}\right)^{16}$. This programme of illumination contained twenty-six miniatures arranged into three narrative cycles, each of which depicted the HN's Norman protagonists in the company of (or in conflict with) their peers, many of whom are addressed directly in the accompanying text and image captions ${ }^{17}$. In fact, it has since been suggested that Dudo's history might have circulated - either from the very outset or from a later point in its manuscript tradition - as an illustrated narrative (chronicon pictum) that was transmitted in the form of precious illuminated manuscripts ${ }^{18}$. If this was the case, then part of the HN's reception during the eleventh and twelfth centuries might have depended less

10. FriIs-Jensen, 1995; Bouet, 1990; StoK, 1999

11. This didactical context was first explored by MORTENSEN, 1995, being pursued further by GELTING, 2013.

12. MoRTENSEN, 1995, p. 100-102.

13. Gelting, 2013, p. 12

14. Ibid., p. 18.

15. Shopkow, 1989; Vopelius-Holtzendorff, 1969; Pohl, 2015, p. 193-195.

16. Shоркоw, 1997, p. 212-245. More recently POHL, 2013, p. 244-257; POHL, 2015, p. 182-197. To facilitate cross-referencing, I will continue to use the manuscript sigla established in ibid., p. xi.

17. PoHL, 2015, p. 184-185.

18. PoHL, 2015b. 
on the respective levels of literacy (or Latinity) amongst its recipients, and more on visual modes of communication. For the purposes of this study, which again focuses on the material nature of the text, I shall follow this latter line of thought. As I have pointed out elsewhere, however, the two theories concerning the $H N$ 's target audiences should not be considered as mutually exclusive ${ }^{19}$. One crucial aspect that both have in common concerns the possibility of an oral or performative context for Dudo's work. In using these terms, I am referring, first of all, to the elementary modes of communication that underlie the presentation and reception of a given text (whether medieval or modern) between a sender and a receiver (or several receivers), usually involving multiple channels of communication that rely on specific codes and conventions ${ }^{20}$. More specifically, I am thinking of Richard Bauman's definition of performance as "an aesthetically marked and heightened mode of communication" that is "put on display for an audience" ${ }^{21}$. Based on Bauman's work, Karl Reichl and Joseph Harris suggest a model for studying different modes of performance in medieval literary culture that understands performance as part of an "event", that is, a creative act that can be "described and located in time and place (its setting) or [...] in a context which has various possible relations to performance itself" ${ }^{22}$.

Scholars working on the material transmission of medieval literature have long acknowledged that some manuscripts were designed deliberately to remain in keeping with oral styles of composition, thus facilitating additional modes of reception ${ }^{23}$. The prevalence of oral conventions that continued to operate even after their codification in writing has been referred to by Albert Lord as "oral residue" 24 , whilst John Foley considers the texts themselves as being "oral-derived" 25 . We should, of course, remember the cautionary words of Reichl, arguing that we must not equate processes of the texts' "transposition" (Verschriftung) with those of their "transformation" (Verschriftlichung) - with the former primarily denoting a change of medium from spoken into written language, and the latter describing the actual recasting of oral registers into written discourse ${ }^{26}$. It is therefore probably prudent to follow Paul Zumthor's suggestion and speak not of "orality" (oralité), but of "vocality" (vocalité), thereby focusing more specifically on the application of oral registers in a transitional context ${ }^{27}$. In a similar vein, Joyce Coleman in her study on public reading during

19. PoHL, 2015, p. 255-256

20. HARris and ReICHL, 2012, p. 142.

21. Quoted in ibid., p. 143.

22. Ibid.

23. For example, Lord, 1995; Foley, 1995; BUSBy, 2002.

24. LORD, 1995, p. 20.

25. FOLEY, 1995, p. 32. Foley introduces the term "oral-derived" in response to Burton Raffel's concept of texts that are "oral-connected".

26. ReICHL, 2012, p. 8-9.

27. Zumthor, 1987, p. 21: “Au moment qu'elle l'énonce, la voix transmue en 'icône’ le signe symbolique délivré par le langage: elle tend à le dépouiller, ce signe, de ce qu'il comporte d'arbitraire; elle le motive de la présence de ce corps dont elle émane; ou bien, par un effet contraire mais analogue, avec duplicité elle détourne du corps réel l'attention, dissimule sa propre organicité sous la fiction du 
the later Middle Ages introduces the term "aurality" in order to emphasise the reciprocal relationship between oral and written modes of reception within medieval reading cultures. In her definition, aurality can be distinguished from orality based on "its dependence on a written text as the source of the public reading" ${ }^{28}$. In an aural setting, the audience shows a fundamental awareness of the fact that whatever is being read out or performed in front of their eyes (and ears) goes back to a written text, for example, a manuscript. It is in this sense that I would now like to explore the possibility of an aural context for the $H N$, thereby hoping to showcase it as a text that rather naturally lent itself to being read (or read out) in a performative setting. This is not to suggest, however, that the written contexts of reception identified in previous scholarship should be considered invalid. On the contrary, my aim here is to scrutinise additional (rather than alternative) settings of a text that was in many ways exceptional, and whose legacy continued to be felt strongly throughout the eleventh and twelfth centuries, both in Normandy and beyond.

Today, the $H N$ survives in a total of fourteen manuscripts produced between c.1050-75 and c.1625-38 ${ }^{29}$. None of these manuscripts represents Dudo's autograph, and not all of them preserve the text in its entirety. Similarly, not all of these copies maintain the work's original prosimetric style, as some of the scribes decided (or were commissioned) to copy only the prose text from their exemplars - a task which they accomplished with varying levels of success ${ }^{30}$. In some cases, the poems appear to have been omitted for aesthetic reasons, due, for example, to changes in literary tastes and conventions. In other cases, however, the reason for their omission seems to have had more to do with the varying levels of Latinity and literary qualification amongst the $H N$ 's eleventh- and twelfthcentury copyists. As I have demonstrated elsewhere, many of the twelfth-century scribes, particularly those in Anglo-Norman England, reveal serious difficulties in copying the prosimetrum, especially when trying to penetrate Dudo's complex and classicising metrical poetry ${ }^{31}$. In several cases this led to serious textual corruption, fundamentally affecting both the poems' metrical structure and their semantic integrity. Notwithstanding these unfavourable conditions, six manuscripts preserve the $H N$ ss prosimetric structure more or less intact. These are, in rough chronological order: Rouen, Bibliothèque Municipale, ms 1173/Y11 (ms R, written at Jumièges c.1050-75); Cambridge, Corpus Christi College, ms 276

\footnotetext{
masque, sous la mimique de l'acteur à qui pour une heure elle prête vie. À l'étalement prosodique, à la temporalité du langage la voix impose ainsi, jusqu'à les gommer, son épaisseur et la verticalité de son espace. C'est pourquoi je préfère, au mot d'oralité, celui de vocalité, c'est l'historicité d'une voix: son usage". Also cf. ReICHL, 2012, p. 18. For a critique on Zumthor's concept of vocalité in the light of other literary and cultural theories on medieval orality and literacy, see CHINCA and Young, 2005, p. 5. Also cf. Coleman, 1996, p. 20-33.

28. Coleman, 1996, p. 28. On Coleman's concept of "aurality", see also Chinca and Young, 2005, p. 7 .

29. For a summary table of the manuscripts, their dates and origins, see PoHL, 2015, p. 262-263.

30. Ibid., p. 102-108; РоHL, 2013, p. 234-244.
}

31. Ibid. 
(ms Cc, written at St Augustine's, Canterbury, c.110o-25); London, British Library, ms Royal 13 B xiv (ms Lr, written in England, possibly at Canterbury, c.1150-75); Antwerp, Museum Plantin-Moretus/Prentenkabinet, ms 17.2 (ms A, written in England, c.1175-1200); Berlin, Staatsbibliothek Preußischer Kulturbesitz, ms Phill. 1854 (ms Be, written at Mont-Saint-Michel, c.1175-1200); London, British Library, ms Cotton Nero D viii (ms Ln, written in England, possibly at Colchester, c.1175-1200 $)^{32}$. By comparing and analysing the way in which Dudo's poetry is presented in these six manuscripts, I hope to be able to tease out some clues regarding the work's possible contexts of reception.

Let us begin by examining the use of punctuation in the surviving manuscripts. It is no secret that the punctuation of medieval manuscripts constitutes a topic that is notoriously complicated and, possibly for precisely that reason, continues to be subject to scholarly debate. The extensive range of contexts in which punctuation has been studied, above all by Malcolm Parkes in his Pause and Effect, ranges from the mechanics of classical grammar and rhetoric to the study of sounds produced in the context of medieval liturgy and music ${ }^{33}$. What these studies have shown beyond reasonable doubt is that in medieval manuscript culture punctuation was not limited to the needs of syntax, but took an active and integral part in the generation of meaning. Throughout the Middle Ages, punctuation fulfilled at least three concrete and co-equal functions, the first of which was prosodic, the second syntactic and the third semantic. In theory, these three functions were distinct from one another, whereas in practice they were often inseparable. From as early as the first century, a fixed system of notae was used in order to distinguish semantic units in lines of verse, with the paragraphus marking the beginning of a section and the simplex ductus separating one subject (res) from another ${ }^{34}$. At the same time, punctuation was employed regularly in the rhetorical analysis of sentences (periodi) by means of commata/incisa and cola/membra, which in certain instances were geared more specifically towards oral recital by dictating the length of, and pauses for, breath $^{35}$. Particularly in respect of public performance, but also during private reading, the semantically-correct delivery of a text thus depended on the reader's ability to vocalise what was written out before him or her. In fact, it has been argued that " $[\mathrm{d}]$ espite disagreement about the creation, transmission and precise form of oral delivery, medievalists generally concur that medieval poetry came to life, as it were, only as spoken, recited or sung poetry" ${ }^{36}$. It has even been proposed that "indispensable as written documents may be for us, in their own

32. For a fuller description and collation of these manuscripts, see PoHL, 2015, p. 18-33. On ms Ln in particular, see POHL, 2015b.

33. Parkes, 1992. Also cf. Derolez, 2003, p. 185. For a study of punctuation in vernacular verse manuscripts, see BUSBY, 2002, vol. 1, p. 155-182. The use of punctuation to indicate vocal or musical qualities in medieval Latin manuscripts has been explored in great detail by ZıoLKowsKI, 2007, p. 83-107.

34. PARKeS, 1992, p. 12.

35. Ibid., p. 4 .

36. REICHL, 2012, p. 18. 
time they were above all ancillary products; what mattered ultimately was oral communication" ${ }^{37}$. More often than not, therefore, nuanced punctuation is thought to point towards a manuscript that allowed for at least some form of oral delivery or public performance, or perhaps even teaching ${ }^{38}$. Again, we can see that the two supposedly opposing theories concerning Dudo's prospective audiences - Latin grammar school versus princely/royal court - in reality allow for considerable overlap. Similarly, we should allow for the possibility, if not the strong probability, that one and the same manuscript might have been read privately on one occasion (either silently or aloud, or indeed both) and publicly on another ${ }^{39}$.

These different modes of reception were not considered as distinct in the Middle Ages as they often are in modern book cultures. For medieval audiences, even reading to oneself typically involved some form of vocalisation, be it by reading aloud, murmuring or rumination (ruminatio), a mnemonic technique that was practised widely in monastic settings ${ }^{40}$. Medieval authors and scribes anticipated these different settings by including into their manuscripts certain features that they knew would appeal to both listeners and readers ${ }^{41}$. Punctuation was no exception. Especially in the context of metric poetry, lyric or song, punctuation during the Middle Ages was employed habitually to mark not only the length of the various pauses that had to observed, but also the correct pitch of the reader's voice ${ }^{42}$. If a manuscript's punctuation was disobeyed or interpreted incorrectly, the meaning of the text(s) it contained ran the risk of being corrupted. Nowhere was there a greater and more imminent danger of such textual and semantic corruption than in the context of liturgy and public worship, and medieval writers and their audiences were very much aware of this. Take, for example, St Augustine's famous warning about putting pauses in the wrong places when reading aloud from Holy Scripture, which echoes the concerns that were expressed in a similar vein by St Jerome ${ }^{43}$. From the seventh century onwards, indeed, we can detect a heightened emphasis on uniform punctuation in liturgical contexts, which soon led to the establishment

37. RichteR, 2012, p. 108. Richter's statement forms a response to Michael Clanchy's claim that all writing depends on the prior formulation of language (quoted in ibid.). It has been observed, however, that such arguments sometimes risk being too reductive through their exclusive focus on the oral prefiguration of medieval manuscript culture; see, for example, SAENGER, 1997, p. 48; SAENGER, 1982.

38. On the use of punctuation in the medieval classroom, see especially GrotANs, 2006, p. 223-250.

39. BusBy, 2002, vol. 1, p. 156.

40. Chinca and Young, 2005, p. 4. Also cf. the arguments for an "intermediate mode of reception" in GrEen, 1994, p. 169-202. There is still debate as to whether the concept of "quiet reading" existed at all during the early and central Middle Ages; see CARruthers, 2008, p. 205-207; CARruthers and Ziolkowski, 2002, p. 19-20. Tessa Webber has announced that her Lyell Lectures (to be held at the Bodleian Library during May 2016) will be devoted to the topic "Public Reading and its Books: Monastic Ideals and Practice in England c.100o-c.1300"; unfortunately, the publication schedule means that it will not be possible to consider her arguments in this article.

41. Chinca and Young, 2005, p. 7.

42. Derolez, 2003, p. 185.

43. Parkes, 1992, p. 35. Also cf. Lord, 1995, p. 19. 
of an increasingly widespread (to avoid the term universal) system of symbols, known as positurae, during the second half of the eighth century. The main symbols used within this system were: the punctus versus (marking the end of a sententia containing a statement); the punctus interrogativus (inserted at the end of a sententia containing a question); the punctus elevatus (marking a major medial pause within a sententia where the sensus is complete but the sententia is not); the punctus flexus (used to mark a minor medial pause within a sententia where the sensus is complete but the sententia itself is not $)^{44}$. The punctus flexus was the last of these symbols to have been introduced, occurring regularly in manuscripts from the tenth century onwards. The earliest known example of a non-liturgical manuscript using the punctus versus has been identified as a mid-eighth-century copy of Bede's Historia Ecclesiastica gentis Anglorum (today London, British Library, ms Cotton Tiberius A xiv) ${ }^{45}$. The first positurae to be inserted regularly by medieval scribes and copyists alongside the traditional distinctiones were naturally those that offered new functions, for example, by indicating a change of pitch as did the punctus interrogativus ${ }^{46}$.

By the time that Dudo composed his work, this system was already firmly in place. In the absence of an autograph, it is impossible to know what the HN's original punctuation looked like, or indeed whether the autograph manuscript showed any punctuation at all. The only potential clues are provided by the copies that have survived from the eleventh and twelfth centuries. It is, of course, perfectly possible that the scribes of these copies superimposed their own scribal customs and altered the punctuation found in their respective exemplars (be they the lost autograph or intermediate copies) by adding certain positurae, for example, or by omitting others which they and/or their audiences considered superfluous. It is no surprise, therefore, to find that a large variety of punctuation is used, with varying frequency and regularity, in the six manuscripts that form the focus of this investigation (see Appendix 1). With the possible exception of the punctus flexus, the positurae found in the HN's poems can all be seen as fulfilling specific functions in conveying their structure and meaning to the audience. I will return to this below. Between the six manuscripts, the punctus elevatus features in a total of 159 poems (44.3\%), closely followed by the punctus versus, which occurs in 137 poems (38.2\%), and the punctus interrogativus, which can be found in 63 poems (17.5\%) (Graph 1) ${ }^{47}$. Some of these poems exhibit combinations of two or three different positurae. The most frequent combination is that of punctus

44. PARKES, 1992, p. 35-36.

45. Ibid., p. 28.

46. The punctus elevatus was sometimes used alongside or instead of the medio distinctio. On the rationale of diacritical systems of punctuation, including accent marks, during different periods of Latin and Neo-Latin literature, see SteEnbakkers, 1994, p. 80-82. Also cf. PArkes, 1992, p. 28. The use of the punctus versus went into decline from the late eleventh century onwards, when it became replaced by the punctus simplex and, eventually, was rendered obsolete.

47. It should be noted that these numbers do not reflect each individual occurrence of a positura within a given poem, rather the overall amount of poems which exhibit examples of positurae (be it single or multiple instances). 
elevatus and punctus versus, which occurs in a total of 78 poems (32.2\%), followed by punctus elevatus plus punctus interrogativus (8 poems; $3.3 \%$ ) and punctus interrogativus plus punctus versus (7 poems; $2.9 \%$ ). Twelve poems (5\%) combine all three positurae (Graph 2). When assessed individually, two manuscripts stand out with regard to their punctuation: mss $\mathrm{Lr}$ and $\mathrm{A}$. Ms Lr is the older of the two, having been produced in England c.1150-1175. Ms A is also an English manuscript, dating $c .1175-1200$. Whilst the punctuation of mss Be, Cc, Ln and R is at times rather sporadic, the positurae in mss A and $\mathrm{Lr}$ are employed with much greater consistency throughout. Due to spatial constraints, a few concrete examples will have to suffice here. To begin with, the first poem to be encountered in mss Lr and A (and in the HN in general) is Dudo's prefatory address to the book (Allocutio ad librum) ${ }^{48}$. It comprises 51 lines and is composed in what is typically considered the most common, and perhaps also the most influential, poetic metre in the Latin Middle Ages, the Dactylic Hexameter ${ }^{49}$. The Allocutio's punctuation in the two manuscripts consists of the punctus simplex, the punctus elevatus and the punctus versus (Figs. 1 \& 2 ) $^{50}$.

The first example of the punctus elevatus occurs at the end of the Allocutio's third line (O liber interno cum te perscrutor ocello), and there are different possible explanations for its inclusion: on the one hand, the punctus elevatus indicates a major medial pause in the sentence: the sensus is complete, whilst the sententia continues on to the following line ([A]Egre fert animus quod vulgo dicere gestis), being completed by means of a punctus versus in $\mathrm{ms} \mathrm{A}$, fol. $3 \mathrm{v}$. On the other hand, the punctus elevatus in this specific instance might also serve to signal a verbal exclamation, instructing the reader (or orator) to raise his/her voice when addressing the book as if it were a person ("O book! When I scrutinise you..."). It is impossible to know with certainty which of the two functions (prosodic or syntactic) the twelfth-century scribe(s) had in mind, and a combination of the two is, of course, perfectly possible. What remains plausible, meanwhile, is that medieval readers found in the punctuation a means that enabled (and indeed encouraged) them to explore additional settings for the $H N$ 's delivery. Rather than simply processing the Allocutio in a way similar to the prose text by which it is preceded on the manuscript page, the reader was given an opportunity to deliver the text vocally and add drama and performative quality to the reading experience. A similar interpretation can be given for the punctus elevatus at the end of the Allocutio's twelfth line: once again, it indicates the completion of a semantic unit (sensus) at the same time as defining another verbal request directed towards the book itself, as if it were a person rather than an object. This time, the personified book is being urged either to proceed at full speed to the Norman schools (Aut pergas northmannica nunc gimnasia praepes) or be cloistered forevermore in the schools of the Franks (Aut scholis clausis franciscis

\footnotetext{
48. HN, ed. Lair, p. 120-121; HN, transl. Christiansen, p. 7-8.

49. On the Dactylic Hexameter and its importance to medieval versification, see Norberg, ed. ZıоLKowsKi, 2004, p. 58-59.

50. In $\mathrm{ms} \mathrm{A}$, the punctus simplex sometimes takes the form of a comma.
} 
iam moruleris $)^{51}$. As with the previous example, we are dealing with a speech that augments the basic channels of communication between the author (as the sender) and his audience (as the receiver) by introducing additional agents in the form of historical and/or, in the case of the personified book, fictive personae ${ }^{52}$. The use of such (fictive) speeches is a literary device that features prominently throughout the $H N$ and its manuscript tradition ${ }^{53}$, and I will return to this below.

The use of the punctus elevatus as a means of instructing the reader to exclaim individual words and sentences emphatically is well known from liturgical manuscripts and, of particular interest in the context of this study, from medieval vernacular verse, where the punctus elevatus was attached regularly to verbal exclamations such as, for example, the Old French "He" and "Ha" ${ }^{54}$. We know that Old French (incl. Anglo-Norman) literature was received habitually (if not predominantly) in aural settings, especially within courtly environments, and we should entertain the possibility that similar contexts of reception might also be applicable to the $H N$ and its audiences during the eleventh and twelfth centuries. Jan Ziolkowski has presented a compelling interpretation of the Allocutio that serves to support this possibility: Ziolkowski argues that the emphatic tone of Dudo's request as to the HN's reception and rapid dissemination within Normandy, rather than at the Frankish schools (which are presented as of secondary importance), might indicate that "the Normans had exacting literary standards", and that "the [Norman ducal] court would not embrace with open arms just any poet" ${ }^{55}$. If poetic excellence was such a central leitmotif of the thriving literary scene in and around Rouen, then it would have made perfect sense for Dudo and his later copyists to accentuate the HN's presentation further by using punctuation that, in addition to its semantic and syntactic function (both of which it played no doubt), also facilitated prosodic reading and encouraged recital within aural settings. The punctus elevatus used in the Allocutio and elsewhere in the text to emphasise verbal exclamations and direct speeches seems an appropriate choice for this task, which was adopted not only by the scribes of mss A and Lr, but amongst some of the HN's other copyists, too. We can see this, for example, in ms Cc, as I will now demonstrate.

Like mss A and Lr, ms Cc is an English manuscript; it was produced at St Augustine's, Canterbury c.110o-1125. Generally speaking, ms Cc makes less (and also less consistent) use of punctuation than mss A and Lr. Amongst the limited cases of punctus elevatus found throughout this manuscript, those that figure most prominently are attached to the Allocutio and other examples of speeches throughout the text (cf. Appendix 1). These include, for example, the poem $O$ trinium specimen... (Nr. 9), which is composed in Elegiac Couplets and features a divine invocation (Te praestante Deus qui cernens omnia

51. HN, ed. Lair, p. 120; HN, transl. Christiansen, p. 7.

52. Cf. HARris and REICHL, 2012, p. 142.

53. POHL, 2015, p. 182; POHL, 2013, p. 255.

54. Busby, 2002, vol. 1, p. 168-169.

55. ZIOLKOWSKI, 1989, p. 46. 
solus / Regnas et vivis et sine fine manes = "Aideth by thee, O God, who seeth all, and alone / ruleth and liveth, and remaineth without ending") ${ }^{56}$. Inserted between the two verses we find a punctus elevatus that, similar to the examples discussed above, encourages the reader to raise his/her voice, at the same time as marking the end of a syntactic unit. The second verse is succeeded by a punctus versus in mss A and Lr, where it completes both the semantic and structural units of composition (Fig. 3 ) $^{57}$. The punctus elevatus, by contrast, features not only in mss A and Lr, but also in mss Cc and Ln at the same textual juncture. The same also holds true with regard to the exclamatory verses in the song addressed directly to Duke Richard I by the Muse Clio (Nr. 41) (Fig. 4), as well as those in the poems Terra ferax... (Nr. 50) and O semper meritos... (Nr. 56), together with several other examples which for reasons of space cannot be discussed here. However, it must be noted that there are also some instances where the use of positurae is less predictable, such as, for example, in the poem $O$ te magnanimum... (Nr. 2), which is composed in the rare Phalaecian Hendecasyllabic Pentameter ${ }^{58}$. The first eleven lines of this poem all commence with an exclamatory "Oh Richard...", which is not, however, followed by a punctus elevatus. Indeed, the majority of the surviving manuscripts use no punctuation whatsoever for this poem (with the exception of ms Cc), whilst ms A employs the punctus versus instead of the punctus elevatus (Fig. 5). We must be careful, therefore, not to overstretch the evidence. This said, the examples of punctuation discussed so far provide at least hints, ranging from implicit to explicit, of a possible aural setting for the $H N$, and they are strong and frequent enough to warrant further scrutiny.

Before moving on to the final part of this study, a few examples should be discussed concerning the use of the punctus interrogativus. Overall, the punctus interrogativus features less prominently in the surviving manuscripts than do its two counterparts discussed above (the punctus elevatus and the punctus versus). It occurs for the first time in the poem Turbinibus variis... (Nr. 3), where it can be seen at the end of the poem's sixteenth line (Elicere humanis possum digesta labellis). Here, the punctus interrogativus serves to mark the end of the question that is established by the pronoun qui ("how?") found at the beginning of previous verse (Qui nec privatim casus nec publice gesta), at the same time as instructing the reader (or orator) to adjust the pitch of his/her voice at the end of the verse ${ }^{59}$. Three of the extant manuscripts (mss A, Cc and Lr) show the punctus interrogativus in this exact position (Fig. 6) ${ }^{60}$. In the poem Rollo quid horrescis... (Nr. 16), composed in the Dactylic Hexameter, the punctus interrogativus is used

56. HN, ed. Lair, p. 128; HN, transl. Christiansen, p. 14.

57. Placed in the middle of the first verse and marking the caesura is a raised punctus (at about half the line's height). For similar cases, see BusBy, 2002, vol. 1, p. 160.

58. Cf. HN, transl. Christiansen, p. 236.

59. HN, ed. Lair, p. 122; HN, transl. Christiansen, p. 8. Also cf. Parkes, 1992, p. 35-38.

60. Further examples of the punctus interrogativus include the poems Rollo quid enteris... (Nr. 19); O Guillelme sacer... (Nr. 27); Viribus ha nocuis... (Nr. 31); Dux et marchio... (Nr. 48); O Ludovice... (Nr. 62); Inventor sceleris... (Nr. 65); Huius patricii... (Nr. 88) (cf. Appendix 1). 
repeatedly in a series of seven subsequent questions which form the poem's opening verses: "Rollo, what do you fear, that you waver in terror and trembling?" (Rollo quid horrescis titubans metuisque vacillans); "Why do you torture your mind so, filled with pestilent thoughts?" (Quid torques animum meditatus peste repletum); "Why do you burn internally, filled with dismal anxiety?" (Quid cor comburis curarum sorde refectum); etc. (Fig. 7) ${ }^{61}$. All but one manuscript (ms R) make similar use of the punctus interrogativus in this position, which demonstrates a much greater consistency than can be observed with regard to the use of either the punctus elevatus or the punctus versus. What is of particular interest, moreover, is the observation that the poem Rollo quid horrescis... shows traces of rhyme in addition to its metric structure, and the same is true of the poem O Deus omnipotens... (Nr. 18). In both cases, an "internal rhyme" (Binnenreim) can be detected either side of the medial caesura, thus establishing a link between the final syllables of each half-line (titubans - vacillans; animum - repletum; curarum - refectum; etc.). These cases of internal rhyme are significant, as they lead us more firmly into the realm of aural delivery.

Unlike most poetry inherited from Antiquity, medieval versification (both Latin and vernacular) was much more receptive to the use of rhyme in addition to (and progressively in lieu of) poetic metre. During the early and central medieval period, rhyme became closely linked with oral delivery ${ }^{62}$, being popularised in various different styles and formats including the widely-used Leonine Hexameter ${ }^{63}$. As I have shown in a recent study, the $H N$, too, obtained a series of Leonine Hexameters at some point during its manuscript tradition ${ }^{64}$. Whether these formed part of Dudo's original design or were introduced by a later copyist is difficult to ascertain, but the surviving evidence ( $\mathrm{ms} \operatorname{Ln}$ in particular) allows for the possibility that the Leonine Hexameters featured in the work from the very beginning. What seems certain, meanwhile, is that they operated as image captions (tituli) for a fully-fledged programme of illumination that could be reconstructed on the basis of one of the $H N$ 's later eleventh-century copies $(\mathrm{ms} \mathrm{R})^{65}$. Within this programme, each image and accompanying titulus corresponds neatly to a fictive speech that in the text is delivered by one of the HN's protagonists. Similar to other examples of illustrated historiography such as Otto of Freising's Chronica, Peter of Eboli's Liber ad honorem Augusti and, not least, the Bayeux Tapestry (but probably predating either of these works by several generations), the $H N$ circulated in the shape of an illuminated chronicle (chronicon pictum) by c.1050-75, if not earlier. As a result, it depended not only on written modes of reception, but also - and fundamentally so - on visual (images) and aural (rhyme) ones. In addition to punctuation, imagery and rhyme, what

61. HN, ed. LAir, p. 145; HN, transl. Christiansen, p. 29.

62. TeViotdale, 1996, p. 99-100. On the significance of rhyme in medieval Latin verse, see NorberG, ed. Ziolkowski, 2004, p. 31-47. Also cf. Dronke, 1970, p. 80-81.

63. Norberg, ed. Ziolkowski, 2004, p. 59-60; PoHL, 2015b, p. 235-236.

64. Ibid., p. 224-233.

65. Ibid., p. 222 
further distinguishes the mise en page of the $H N$ 's surviving manuscripts is their extensive use of rubrics, some of which serve to elucidate the poems' often complex metrical structure. Altogether, there are forty-nine such "explanatory rubrics" throughout the text, making them the largest group of rubrics by quite some margin (most of them are preserved in mss A, Cc and Lr) ${ }^{66}$. A second group found in the same manuscripts seems to fulfil a more specific function by announcing speeches or other pieces of dialogue, for example, in the form of orations ${ }^{67}$, dedications ${ }^{68}$, and songs. Good examples of this kind of rubric - which we might call "vocalising rubrics" - can be found at the beginning of the HN's fourth book, where the Nine Muses together perform various songs of praise in honour of Richard I (Figs. 8-10) ${ }^{69}$. The Latin terminology employed by these rubrics might hold additional clues concerning the poems' presentation. Some of the most frequently used terms include oratio ("speech"), concentus ("harmony")"choir") and carmen ("song"), but we also find verbs such as loqui ("to speak") and canere ("to sing"/"to recite"). It is perfectly possible, of course, that these terms, too, were intended as didactic or explanatory devices, especially if we embrace the possibility that the $H N$ might have been used as a school book aimed at students of Latin. Still, in the light of the evidence discussed in this article, I shall like to propose a supplementary explanation that primarily recognises the rubrics as potential instructions for vocalisation.

This hypothesis can be supported further by the sophisticated use of colour in several of the HN's extant manuscripts (most vividly perhaps in ms A). Scholars have demonstrated that medieval scribes often used colour in order to render the contents of the page more accessible to the eyes of the reader and facilitate oral recital, for example, in the shape of coloured initials or litterae notabiliores ${ }^{70}$.

66. See the summary table in PoHL, 2015, p. 264-267. The style of these rubrics is reminiscent of that found in didactical treatises from the early Middle Ages, for example, in Bede's De arte metrica. The rubrics' length and detail vary considerably, ranging from single words (Eroicum; ms Cc, fol. 125v) and basic explanations (Metrum heroicum cum elegiaco; ms A, fol. 42r; ms Cc, fol. 93v; $\mathrm{ms} \mathrm{Lr}$, fol. 4or) to fully-fledged metrical commentaries (Metrum tetracolon tetrastrophon id est quattuor metri generibus a quarto facta replicatione. Habet enim primum versum adonium secundum archilodium tercium feretacium quartum gliconium; ms A, fol. 27v; ms Cc, fol. 79r; ms Lr, fol. 22v).

67. Examples include: Oratio (Nr. 9 - ms A, fol. 6v; ms Cc, fol. 59v; ms Lr, fol. $5 \mathrm{r}$ ); Oratio eleiaco carmine decursa (Nr. 14 - ms A, fol. 11v; ms Cc, fol. 64v; ms Lr, fol. 8r); Oratio Rollonis (Nr. 18 - ms A, fol. 15 r; ms Be, fol. 19v; ms Cc, fol. 68v; ms Ln, fol. 83r; ms Lr, fol. 11v; ms R, fol. 11r); Oratio (Nr. 26 - ms A, fol. 27v; ms Be, fol. 33v; ms Cc, fol. 79r; ms Ln, fol. 91v; ms Lr, fol. 28v; ms R, fol. 18v); Oratio (Nr. 54 - ms A, fol. 44r; ms Be, fol. 48v; ms Cc, fol. 95v; ms Lr, fol. 42v; ms R, fol. 3 or). It has been observed that some of the $H N^{\prime}$ 's orations bear strong resemblances to Carolingian sermons and homilies; see HN, transl. Christiansen, p. xxxii-xxxiv. This is perfectly in line with the "Carolingian heritage" that scholars have identified in the composition of Dudo's work, for example, PoнL, 2012; Sноркоw, 1989, p. 26-27.

68. For example, Hic clericus ad Franciam loquitur = "Here the cleric speaks to Francia" (No. 10 - ms A, fol. 1or; ms Cc, fol. 62v); Hic loquitur ad librum = "Here one talks to the book" (Nr. $53-\mathrm{ms} \mathrm{A}$, fol. 43v; ms Cc, fol. 95r; ms Lr, fol. 42r).

69. Exhortatio ad musas ut canant Richardum (Nr. 40 - ms A, fol. 42-v; ms Be, fol. 47r; ms Cc, fol. 93v; ms Lr, fol. 4or; ms R, fol. 28v); Parilis concentus musarum quod cum coniugatis continentibus et virginibus remuneretur (Nr. 49 - ms A, fol. 43-v; ms Cc, fol. 94v; ms Lr, fol. 41v).

70. PARKES, 1992, p. 42. 
From the Carolingian period onwards, scribes copying Latin poetry increasingly employed coloured initials as a means of designating individual lines of verse visually, sometimes by inserting a small space for added emphasis (as can be seen in $\mathrm{ms} \mathrm{Be}$, fol. $17 \mathrm{v}$ and $\mathrm{ms}$ Lr, fol. 11r). During the twelfth century, similar practices can also be observed regularly in the copying of vernacular poetry ${ }^{71}$. Some of the most elaborate uses of colour in the $H N$ 's manuscripts include ms A, fol. 3v-6v (Nr. 1-9), fol. 10v-11v (Nr. 11-14) and fol. 26v-28 (Nr. 24-26) (see Figs. 1, 3 \& 11). Here, we can see strictly alternating initials painted in up to three different colours (red, green and blue $)^{72}$. Being inserted the beginning of each new verse, they allow the reader (or orator) quickly to process the poems' structure without skipping a verse. Whilst such visual navigation aids were no doubt useful to a variety of potential users operating in different contexts of reception, they unfolded their maximum potential in settings where the poems were either memorised or read aloud. The mnemonic and performative power of visual clues like the colour and shape of letters (color et forma litterarum) was well known during the eleventh and twelfth centuries, being explained most memorably by Hugh of Saint-Victor ${ }^{73}$. As with punctuation, the use of colour and other visual clues are likely to have fulfilled a variety of functions, some of which might have been practically motivated (for example, in the capacity of aide-mémoires), others aesthetically; some appear to have been aimed primarily at the scribe, others at the reader or orator. In many instances, these functions were not mutually exclusive, but probably operated in reciprocity and even supported one another. The intrinsic functional relationship between manuscript punctuation, decoration and mise en page has been expressed most succinctly by Parkes' observation that " $\mathrm{t}$ ] he rôle of punctuation in verse is inextricably bound up with the functions of layout and the graphic manifestation of rhyme in the presentation of texts for readers" 74 . In a similar vein, Busby has argued that "in practice, even a verse manuscript with no decoration at all is punctuated by usually being laid out on the page as verse" 75 . That this also holds true for the layout of the HN's poems is easy to observe. The examples that best illustrate how the layout of a poem could benefit the reader include ms A, fol. 27v-28r (Nr. 26), ms Ln, fol. 91v (ibid.), ms Be, fol. 94v (Nr. 62) and ms R, fol. 36r (ibid.). In each case, it is the use of a multi-column layout that guides the reader's eye and helps him or her to navigate the page with confidence, supported by the use of both colour and punctuation. Given the various benefits that such layouts held for medieval scribes, it is not difficult to imagine how much greater still their impact would have been within an aural or performative setting.

71. BusBy, 2002, vol. 1, p. 156-158.

72. Similar examples can be found in ms Be, fol. $4 \mathrm{r}-8 \mathrm{v}$ (Nr. 1-9) and ms Lr, fol. 2v-5r (ibid.), where the litterae notabiliores alternate between red and green throughout, as well as in $\mathrm{ms} \mathrm{R}$, fol. $3 \mathrm{r}-\mathrm{v}$ (Nr. 4-8), where the two colours used are red and brown (the ink used for copying the main text).

73. Green, 1943, p. 290. Also cf. Carruthers, 2008, p. 264.

74. PARKeS, 1992, p. 97.

75. BUSBY, 2002, vol. 1, p. 156 
I now return to the topic that was touched upon at the outset of this study, namely the identification of the $H N$ 's possible target audience(s). Prima facie, the elaborate use of punctuation and other visual clues in the surviving manuscripts seem to point towards a learned audience whose members were capable of "decoding" these clues and translating them into practice. From this perspective, the reception of the text in the context of Normandy's grammar schools must remain a plausible scenario. However, this is not the only possible conclusion that can be reached on the basis of the manuscript evidence discussed in this article. In his study and edition of the Moriuht - a poem written by Warner of Rouen during the early eleventh century and dedicated to Archbishop Robert of Rouen and his mother, the Duchess Gunnor -, Christopher McDonough proposes to distinguish between what he calls the "actual" and "authorial audiences" of a text ${ }^{76}$. McDonough argues that whilst the Moriuht's authorial (or intended) audiences would have had to be familiar with the fine subtleties and intricate nuances of Latin literature, the poem's actual audiences almost certainly possessed a much more basic understanding of the language, that is, if they understood Latin at all. This does not mean, however, that they had no way of appreciating a complex and sophisticated work of literature such as Warner's. As McDonough demonstrates, there is a strong possibility that the Moriuht was received not only in writing, but equally (if not indeed primarily) by means of performance and/or oral translation ${ }^{77}$. Can a similar argument be made with regard to Dudo's work, too? Traditionally, it has been argued that the Norman elites at Rouen cannot have constituted the HN's actual audience, given that the levels of literacy (or Latinity) amongst its members were insufficient to appreciate the stylistic and rhetorical finesse of Dudo's complex literary composition ${ }^{78}$. More recently, scholars have revisited these arguments and presented evidence to the contrary, suggesting instead that the Norman dukes and their peers could have engaged with the text through different channels of communication ${ }^{79}$. This has led to a more nuanced understanding of categories such as "literacy"/ "illiteracy" along with a stronger focus on literary agency ${ }^{80}$. According to this school of thought, aurality and literacy must not be considered as two separate forms of communication, rather as two modes that as operated reciprocally ${ }^{81}$.

76. McDonough, 1995, p. 51. Also cf. van Houts, 2000, p. 92.

77. Ibid., p. 52-54. On the topic of translation, see TYLER, 2005, p. 370-371.

78. This point has been made most prominently by Sноркоw, 1989, p. 30-31.

79. See Mortensen, 1995, p. 101. Also cf. Pohl, 2015b.

80. On principal discussions of literacy and illiteracy and their usefulness as concepts for historical research, see especially B̈̈UML, 1980, p. 239; STOCK, 1983, p. 30-87; ClAnChY, 2012, p. 192-199. Also cf. REICHL, 1995, p. 10-11. A good overview of previous scholarship is provided in GREEN, 1994, p. 8-10. The importance of literary agency is also emphasised explicitly by TyLER, 2005, p. $365-366$.

81. GreEN, 1994. On what has since become known as the "weak" theory concerning the mutual relationship between medieval orality and literacy, see COLEMAN, 1996, p. 74-75; CHINCA and Young, 2005, p. 4. Also cf. MCKitTerick, 1989, p. 323. 
If aural contexts of reception can be considered as having played at least some part within Normandy's literary milieu during the eleventh and twelfth centuries, arguably it would have been most intimately connected with the presentation of poetry and verse ${ }^{82}$. In her case study on the Encomium Emmae Reginae (another Latin work from eleventh century Normandy), Elizabeth Tyler has produced compelling evidence to suggest that the text was shaped within an environment of close interaction between the spoken and the written word, with the former claiming primacy over the latter ${ }^{83}$. Indeed, the Encomium's anonymous author seems to have envisaged that his own work would be delivered in an aural context, given that in the preface he refers explicitly to his "listeners" (auditor[es]) ${ }^{84}$. With regard to the contemporary Norman poem known as Semiramis, it has even been suggested that actors might have staged the text in front of secular audiences ${ }^{85}$. Patronage over poetic works such as these was regularly assumed by the Norman dukes themselves, as well as by their spouses (Gunnor) and siblings (Archbishop Robert of Rouen), who likewise constituted key figures in the promotion of historical and literary works ${ }^{86}$. The importance of both Gunnor and Robert as sponsors, and possibly also as consumers, of Norman Latin literature (including Latin poetry) has been proven beyond reasonable doubt $^{87}$, and it seems incontestable that Normandy's (and, after 1066, England's) secular elites must have acquired some form of access to Latin literary culture despite their limited levels of literacy. Franz Bäuml has introduced the helpful term "quasi-literate" as a means of referring to medieval audiences who secured access to literary culture through mediation so as to exercise their socio-political functions ${ }^{88}$. For quasi-literate audiences, aural contexts of reception offered a stimulating environment within which to enjoy literary works, even if they could not read them first-hand. Returning to the $H N$, the inclusion of more than ninety metrical poems throughout the narrative, several of which would have been unfamiliar even to educated audiences, was therefore a deliberate and effective stylistic choice made by the author and/or his patrons. The fact that the (Anglo-)Norman rulers and their peers possessed a rather limited comprehension of Latin, almost certainly not enough to read the $H N$ without considerable assistance, does not mean that we can rule them out as potential recipients of the text. If anything, it should make us re-evaluate the categories and frameworks that we apply in our investigation of medieval literary culture and its audiences.

82. ZIOLKOWSKI, 1989, p. 39-42. In fact, Norman Latin verse regularly went hand in hand with prose, as is exemplified by the Moriuht, the anonymous poems Jezebel and Semiramis and a series of shorter verse epitaphs; see Dronke, 1970, p. 66-113; VAN HouTs, 1992, p. 18-20. To these examples can be added the prosaic work of praise known as the Encomium Emmae Reginae, written during the early 1040 in praise of Emma of Normandy, the daughter of Richard I and his wife Gunnor; see Alistair and Keynes, 1998. Also cf. Tyler, 2005.

83. TYleR, 2005, p. 364-370.

84. Ibid.

85. VAN Houts, 1992, p. 19

86. TYLER, 2005, p. 375.

87. Ibid., p. 375-376. Also cf. McDonough, 1995, p. 52-54; van Houts, 1992, p. 20.

88. B̈̈UML, 1980, p. 246-247. 
As I hope to have shown, investigating the surviving manuscripts and their material features - particularly punctuation, colour, mise en page - can reveal some powerful clues as to the possible settings and contexts within which Dudo's work was received by medieval audiences. There are, of course, certain limitations. First of all, the manuscripts all date from the period c.1050-1200, meaning that they provide little or no concrete information concerning the HN's initial transmission following its publication in or around 1015. The fact that some of the manuscripts show considerable similarities in the punctuation, design and layout of the poems might well suggest that these features derive from earlier exemplars (perhaps even Dudo's lost autograph), but without further evidence, this remains informed conjecture for now. Similarly, it is difficult to build a conclusive argument on the evidence of punctuation alone, given that the positurae used habitually by medieval scribes fulfilled a variety of different functions which, despite their being distinct in theory, were often inseparable in practice. Even though the examples of punctuation discussed here provide strong hints of an aural or performative setting, sometimes implicitly, others more explicitly, it is crucial to understand aurality as an additional, rather than an alternative context. In other words, the evidence presented in this study does not indicate that the $H N$ was received either exclusively or even primarily in an aural setting, but it certainly offers us the possibility that such a setting existed as one of several options from amongst which medieval authors and their audiences could choose, thus enriching our understanding of literary and poetic culture in the Norman and Anglo-Norman worlds.

\section{Bibliography}

BARToŇKovÁ, Daša., "Prosimetrum, the Mixed Style, in Ancient Literature", Eirene, 14,1976 , p. 65-92.

BÄUmL, Franz Henry, "Varieties and Consequences of Medieval Literacy and Illiteracy", Speculum, 55, 1980, p. 237-265.

Boute, Pierre, "Dudon de Saint-Quentin et Virgile: 'L’Énéide' au service de la cause normande", Recueil d'études en hommage à Lucien Musset, Cahier des Annales de Normandie, 23, 1990, p. 215-236.

Busby, Keith, "Mise en texte as Indicator of Oral Performance in Old French Verse", in Performing Medieval Narrative, E. B. Vitz, N. F. Regalado and M. Lawrence (ed.), Cambridge, Cambridge University Press, 2005, p. 61-71.

Busby, Keith, Codex and Context: Reading old French Verse Narrative in Manuscript, Faux Titre, 221, 2 vols., Amsterdam, Rodopi, 2002.

CARruthers, Mary, The Book of Memory: A Study of Memory in Medieval Culture, $2^{\text {nd }}$ ed., Cambridge, Cambridge University Press, 2008.

Carruthers, Mary and Ziolkowski, Jan M. (eds.), The Medieval Craft of Memory: An Anthology of Texts and Pictures, Philadelphia, University of Pennsylvania Press, 2002. 
Chinca, Mark and Young, Christopher C., "Orality and Literacy in the Middle Ages: A Conjunction and its Consequences", in Orality and Literacy in the Middle Ages: Essays on a Conjunction and its Consequences in Honour of D. H. Green, Utrecht Studies in Medieval Literacy 12, ed. M. Chinca and C. Young, Turnhout, Brepols, 2005, p. 1-15.

Clanchy, Michael Thomas, From Memory to Written Record: England 1066-1307, $3^{\text {rd }}$ ed., Oxford, Oxford University Press, 2012.

Coleman, Joyce, Public Reading and the Reading Public in Late Medieval England and France, Cambridge, Cambridge Studies in Medieval Literature, 26, Cambridge University Press, 1996.

Derolez, Albert, The Palaeography of Gothic Manuscript Books: From the Twelfth to the Early Sixteenth Century, Oxford, Oxford University Press, 2003.

Dronke, Peter, Poetic Individuality in the Middle Ages: New Departures in Poetry, 1000-1150, Oxford, Clarendon Press, 1970.

Dronke, Peter, Verse with Prose from Petronius to Dante: The Art and Scope of the Mixed Form, Cambridge, Mass., Harvard University Press, 1994.

Encomium Emmae Reginae, ed. Alistair CAmpbell and Simon Keynes, Cambridge, Cambridge University Press, 1998.

Foley, John Miles, “The Implications of Oral Tradition”, in Oral Tradition in the Middle Ages, William Fritz Henry Nicolaisen (ed.), Medieval and Renaissance Texts and Studies, 112, Birmingham, NY, Center for Medieval and Early Renaissance Studies, 1995, p. 31-57.

FriIs-Jensen, Karsten, "Dudo of St. Quentin and Saxo Grammaticus”, in Dudone di San Quintino, Paolo Gatti and Antonella Degl'Innocenti (ed.), Labirinti - Collana del Dipartimento di Scienze Filologiche e Storiche, 16, Trento, Università degli Studi di Trento, 1995, p. 11-28.

Gelting, Michael, "The Courtly Viking: Education and mores in Dudo of SaintQuentin's Chronicle”, in Toogtredivte tvorfaglige Vikingesymposium, Syddansk Universitet 2013, Lars BisgaArd, Mette BruUs and Peder Gammeltoft (ed.), Højbjerg, Forlaget Wormianum, 2013, p. 7-36.

Green, Dennis Howard, Medieval Listening and Reading: The Primary Reception of German Literature, 800-1300, Cambridge, Cambridge University Press, 1994.

Green, William M., "Hugh of St. Victor: De tribus maximis circumstanciis gestorum", Speculum, 18, 1943, p. 484-493.

Grotans, Anna A., Reading in Medieval St. Gall, Cambridge, Cambridge University Press, 2006.

Harris, J. and K. Reichel, "Performance and Performers", in Medieval Oral Literature, Karl Reichl (ed.), De Gruyter Lexikon, Berlin, De Gruyter, 2012, p. 141-202.

HN. Dudo of Saint-Quentin: De moribus et actis primorum Normanniae ducum, ed. Jules LaIr, Mémoires de la Société des Antiquaires de Normandie, 23, Caen, Le Blanc-Hardel, 1865.

HN. Dudo of Saint-Quentin: History of the Normans, transl. Eric Christiansen, Woodbridge, Boydell \& Brewer, 1998. 
Huisman, Gerda C., “Notes on the Manuscript Tradition of Dudo of St Quentin’s Gesta Normannorum", Anglo-Norman Studies, 6 (1984), p. 122-135.

LorD, Albert B., “Oral Composition and 'Oral Residue' in the Middle Ages”, in Oral Tradition in the Middle Ages, William Fritz Henry Nicolaisen (ed.), Medieval and Renaissance Texts and Studies, 112, Birmingham, NY, Center for Medieval and Early Renaissance Studies, 1995, p. 7-29.

McKitterick, Rosamond, The Carolingians and the Written Word, Cambridge, Cambridge University Press, 1989.

Mortensen, Lars Boje, "Stylistic Choice in a Reborn Genre: The National Histories of Widukind of Corvey and Dudo of St. Quentin”, in Dudone di San Quintino, P. Gatti and A. Degl'Innocenti (ed.), Labirinti - Collana del Dipartimento di Scienze Filologiche e Storiche, 16, Trento, Università degli Studi di Trento, 1995, p. 77-102.

Norberg, Dag, An Introduction to the Study of Medieval Latin Versification, ed. J. M. Zıolkowski, Washington, DC, The Catholic University of America Press, 2004.

Pabst, B., "Dudo und die prosimetrische Tradition", in Dudone di San Quintino, P. Gatti and A. Degl'Innocenti (ed.), Labirinti - Collana del Dipartimento di Scienze Filologiche e Storiche, 16, Trento, Università degli Studi di Trento, 1995, p. 103-131.

PABst, Bernhard, Prosimetrum: Tradition und Wandel einer Literaturform zwischen Spätantike und Spätmittelalter, Ordo Studien zur Literatur und Gesellschaft des Mittelalters und der frühen Neuzeit, 4, 2 vols., Köln, Böhlau, 1994.

Parkes, Malcolm Beckwith, Pause and Effect: An Introduction to the History of Punctuation in the West, Berkeley, Scolar Press, 1992.

Plassmann, Alheydis, "Der Wandel des normannischen Geschichtsbildes im 11. Jahrhundert: Eine Quellenstudie zu Dudo von St. Quentin und Wilhelm von Jumièges", Historisches Jahrbuch, 115, 1995, p. 188-207.

Pohl, Benjamin, "Pictures, Poems and Purpose: New Perspectives on the Manuscripts of Dudo of St. Quentin's Historia Normannorum”, Scriptorium, 67, 2013, p. 229-258.

PoHL, Benjamin, "The Illustrated Archetype of the Historia Normannorum: Did Dudo of Saint-Quentin Write a 'Chronicon Pictum'?”, Anglo-Norman Studies, 37, 2015b, p. 225-255.

PoHL, Benjamin, “Translatio imperii Constantini ad Normannos: Constantine the Great as a Possible Model for the Depiction of Rollo in Dudo of St. Quentin's Historia Normannorum", Millennium, Yearbook on the Culture and History of the First Millennium C.E., 9, 2012, p. 297-339.

PoHL, Benjamin, Dudo of St. Quentin's Historia Normannorum: Tradition, Innovation and Memory, Writing History in the Middle Ages, 1, York: Boydell/York Medieval Press, 2015.

Polheim, Karl Konrad, Die lateinische Reimprosa, $2^{\text {nd }}$ ed., Berlin, 1963.

Reichl, Karl, "Plotting the Map of Medieval Oral Literature", in Medieval Oral Literature, Karl Reichl (ed.), De Gruyter Lexikon, Berlin, De Gruyter, 2012, p. 3-67.

Richter, Michael, “The Written Word in Context: The Early Middle Ages”, in Medieval Oral Literature, Karl Reichl (ed.), De Gruyter Lexikon, Berlin, De Gruyter, 2012, p. 103-119. 
SAenger, Paul, "Silent Reading: Its Impact on Late Medieval Script and Society”, Viator, 13, 1982, 367-414.

SAenger, Paul, Spaces between Words: The Origins of Silent Reading, Stanford, CA, Stanford University Press, 1997.

SChaller, Dieter, "Zu neueren Arbeiten über die prosimetrische Literatur des Mittelalters", Deutsches Archiv für Erforschung des Mittelalters, 54, 1998, p. 613-622.

Sноркоw, Leah, History and Community: Norman Historical Writing in the Eleventh and Twelfth Centuries, Washington, DC, Catholic University of America Press, 1997.

Sноркоw, Leah, "The Carolingian World of Dudo of Saint-Quentin”, Journal of Medieval History, 15, 1989, p. 19-37.

SteEnbakkers, Pieter Maria Leonarus, Spinoza's Ethica from Manuscript to Print: Studies on Text, Form and Related Topics, Assen, Van Gorcum, 1994.

STоск, Brian, The Implications of Literacy: Written Language and Models of Interpretation in the Eleventh and Twelfth Centuries, Princeton, Princeton University Press, 1983.

Sток, Fabio, “L'Eneide nordica di Dudone di San Quintino”, International Journal of the Classical Tradition, 6.2, 1999, p. 171-184.

Teviotdale, Elizabeth C., "Latin Verse Inscriptions in Anglo-Saxon Art”, Gesta, 35, 1996, p. 99-110.

Tyler, Elizabeth M., “Talking about History in Eleventh-Century England: The Encomium Emmae Reginae and the Court of Harthacnut", Early Medieval Europe, 13, 2005, p. 359-383.

Van Houts, Elisabeth M. C., "A Note on Jezebel and Semiramis: Two Latin Norman Poems from the Early Eleventh Century”, Journal of Medieval Latin, 2, 1992, p. 18-24.

Van Houts, Elisabeth M. C., "Rouen as Another Rome in the Twelfth Century", in Society and Culture in Medieval Rouen, 911-130o, L. V. Hicks and E. Brenner (ed.), Studies in the Early Middle Ages, 39, Turnhout, Brepols, 2013, p. 101-124.

Van Houts, Elisabeth M. C., “The Gesta Normannorum Ducum: A History Without an End", Anglo-Norman Studies, 3, 1980, p. 106-118.

Van Houts, Elisabeth M. C., The Normans in Europe, Manchester Medieval Sources, Manchester, Manchester University Press, 2000.

Vopelius-HoltzendorfF, Barbara, "Studien zu Dudo von Saint-Quentin, dem ersten Geschichtsschreiber der Normandie (987-1015)”, PhD Dissertation, University of Göttingen, 1969.

Warner of Rouen: Moriuht, ed. Christopher James McDonough, Studies and Texts, 121, Toronto, Pontifical Institute of Medieval Studies, 1995.

Ziolkowski, Jan M., Jezebel: A Norman Latin Poem of the Early Eleventh Century, Humana Civilitas, 10, New York, Peter Lang, 1989.

Ziolkowski, Jan M., Nota Bene: Reading Classics and Writing Melodies in the Early Middle Ages, Publications of the Journal of Medieval Latin, 7, Turnhout, Brepols, 2007.

Ziolkowski, Jan M., “The Prosimetrum in the Classical Tradition”, in Prosimetrum: Crosscultural Perspectives on Narrative in Prose and Verse, J. Harris and K. Reichl (ed.), Suffolk, D. S. Brewer, 1997, p. 45-66.

Zumthor, Paul, La lettre et la voix de la "littérature" médiévale, Paris, Editions de Seuil, 1987. 


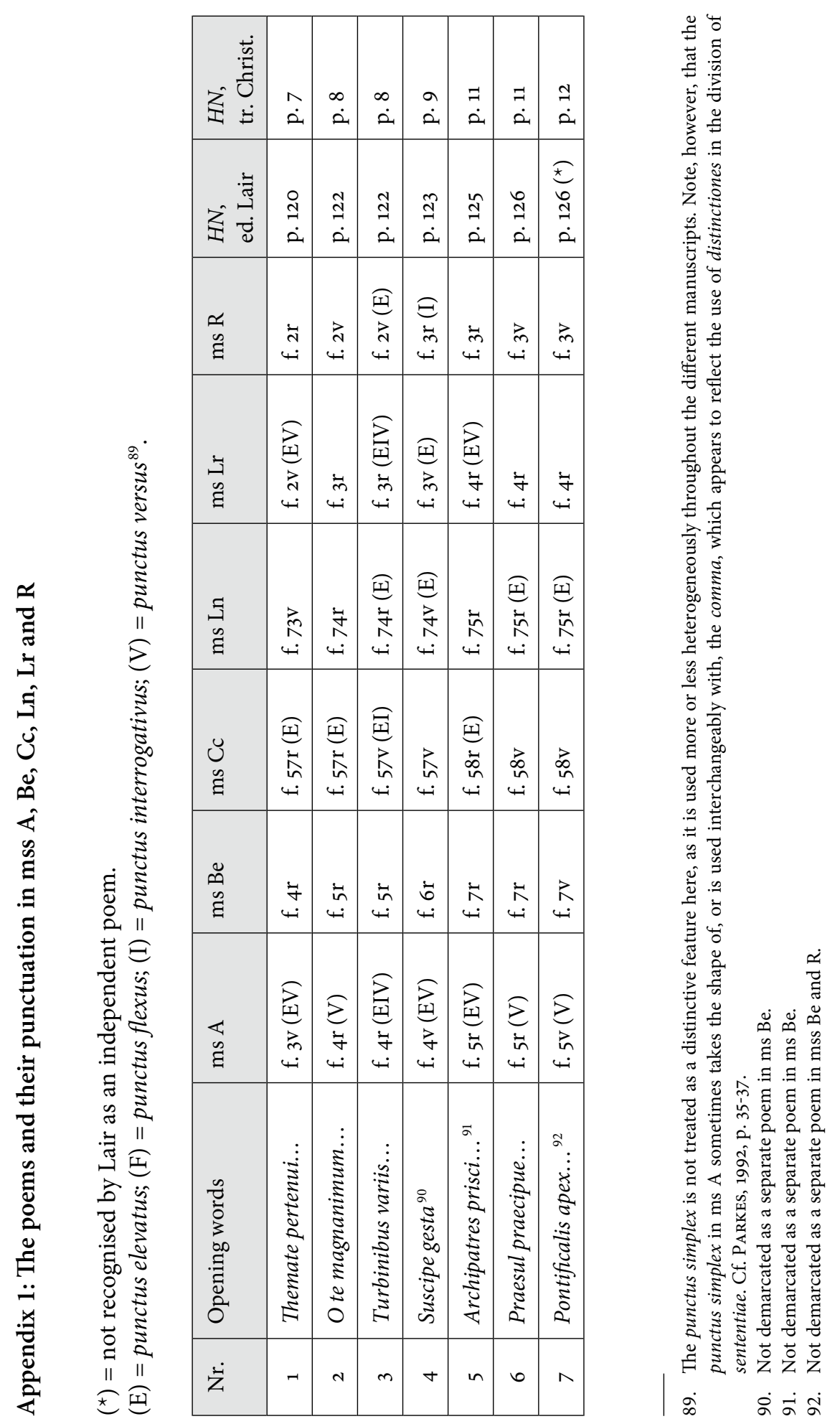

http://www.unicaen.fr/mrsh/craham/revue/tabularia/print.php?dossier=dossier15\&file=02pohl.xml 


\begin{tabular}{|c|c|c|c|c|c|c|c|c|c|c|c|c|c|}
\hline$\stackrel{m}{\dot{m}}$ & $\begin{array}{l} \pm \\
\dot{\Delta}\end{array}$ & $\begin{array}{l}\stackrel{0}{1} \\
\dot{\alpha}\end{array}$ & $\begin{array}{l}\text { N } \\
\dot{2}\end{array}$ & $\begin{array}{l}\tilde{\imath} \\
\dot{\Sigma}\end{array}$ & $\begin{array}{l}\stackrel{+}{2} \\
\dot{2}\end{array}$ & $\begin{array}{l}\text { ते } \\
\text { ¿. }\end{array}$ & 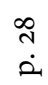 & $\begin{array}{l}\hat{i} \\
\dot{\alpha}\end{array}$ & $\begin{array}{l}\vec{m} \\
\dot{\omega}\end{array}$ & $\begin{array}{l}\tilde{m} \\
\dot{\alpha}\end{array}$ & $\begin{array}{l}\dot{m} \\
\dot{\hat{2}}\end{array}$ & $\begin{array}{l}\stackrel{m}{m} \\
\dot{2}\end{array}$ & \\
\hline $\begin{array}{l}\hat{\jmath} \\
\dot{\lambda}\end{array}$ & 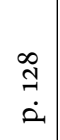 & $\begin{array}{l}\hat{m} \\
\dot{n}\end{array}$ & $\begin{array}{l}\stackrel{\widehat{m}}{2} \\
\stackrel{2}{2}\end{array}$ & 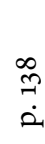 & $\begin{array}{l}\approx \\
\stackrel{\pi}{2} \\
\dot{2}\end{array}$ & 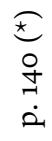 & $\begin{array}{l}\frac{f}{f} \\
\dot{2}\end{array}$ & $\begin{array}{l}\text { nf } \\
\dot{2}\end{array}$ & $\begin{array}{l}\infty \\
\pm \\
\dot{2} \\
\dot{2}\end{array}$ & $\begin{array}{l}\vec{J} \\
\dot{\Delta}\end{array}$ & $\begin{array}{l}\vec{n} \\
\dot{n}\end{array}$ & $\begin{array}{l}\stackrel{\tilde{n}}{2} \\
\dot{n}\end{array}$ & \\
\hline$\stackrel{m}{i}$ & $\begin{array}{l}7 \\
\stackrel{7}{4}\end{array}$ & $\begin{array}{l}\vec{b} \\
+\end{array}$ & $\underset{+}{B}$ & $\underset{+i}{i}$ & $\underset{+i}{i}$ & $\underset{+}{N}$ & 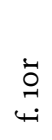 & $\underset{\sim}{\overrightarrow{0}}$ & $\underset{\exists}{\exists}$ & $\begin{array}{l}\vec{\exists} \\
\dot{\Psi}\end{array}$ & 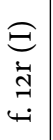 & 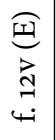 & $\dot{\vec{g}}$ \\
\hline 裉 & 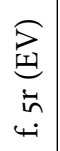 & 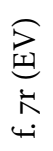 & 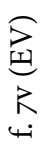 & 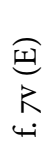 & 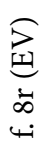 & 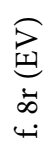 & 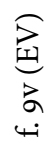 & 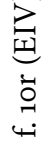 & 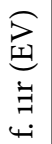 & 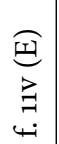 & 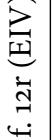 & 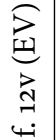 & $\begin{array}{l}\overrightarrow{\tilde{a}} \\
\overrightarrow{3} \\
\overrightarrow{\mathrm{J}}\end{array}$ \\
\hline 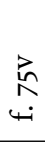 & 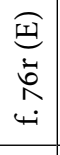 & 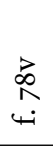 & $\underset{4}{\stackrel{\hbar}{~}}$ & 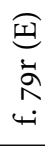 & న & 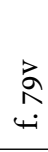 & $\begin{array}{r}1 \\
\infty \\
4 \\
4\end{array}$ & $\begin{array}{l}\Xi \\
\Xi \\
\infty \\
+ \\
+\end{array}$ & 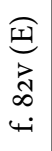 & 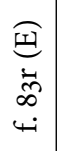 & $\begin{array}{c}E \\
\vec{\infty} \\
\stackrel{\infty}{0} \\
\dot{\sim i}\end{array}$ & 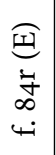 & 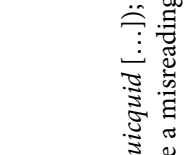 \\
\hline 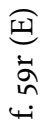 & 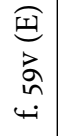 & $\underset{\leftarrow}{\vec{d}}$ & 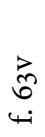 & ڤ్ & $\underset{\leftarrow}{\vec{f}}$ & $\begin{array}{l}\vec{b} \\
\stackrel{+}{*}\end{array}$ & $\begin{array}{l}\overrightarrow{0} \\
0 \\
4\end{array}$ & 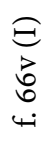 & $\begin{array}{l}\dot{0} \\
\dot{0} \\
\dot{+}\end{array}$ & 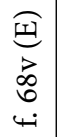 & \begin{tabular}{c}
$\overrightarrow{0}$ \\
\multirow{4}{*}{}
\end{tabular} & $\begin{array}{c}\stackrel{0}{0} \\
\stackrel{\leftrightarrow}{*}\end{array}$ & $\frac{5}{5}$ \\
\hline $\begin{array}{l}\dot{\infty} \\
\leftarrow \\
\Psi\end{array}$ & $\begin{array}{l}\dot{\infty} \\
+ \\
+\end{array}$ & $\underset{+}{4}$ & $\stackrel{\vec{m}}{+}$ & $\stackrel{\vec{m}}{\uplus}$ & $\underset{+}{7}$ & $\underbrace{3}_{4}$ & تٕ & 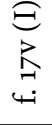 & 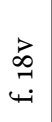 & $\overrightarrow{\vec{T}}$ & 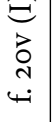 & $\begin{array}{l}\vec{\pi} \\
\dot{\sim}\end{array}$ & 3 \\
\hline 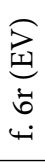 & $\begin{array}{l}\text { 童 } \\
\vdots \\
\vdots \\
4\end{array}$ & 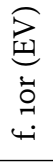 & 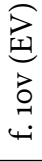 & 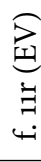 & 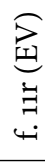 & 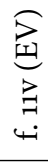 & 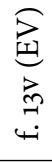 & 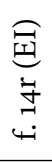 & $\sigma_{1}$ & 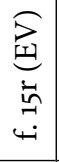 & 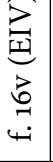 & 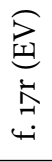 & 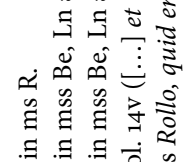 \\
\hline 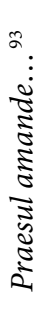 & 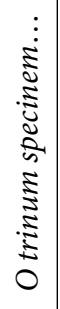 & 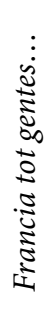 & 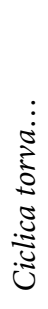 & 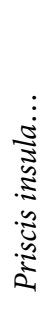 & 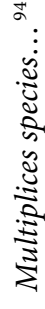 & 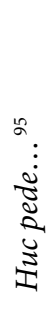 & 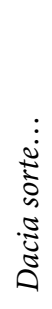 & 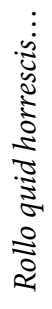 & 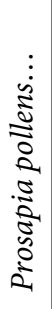 & 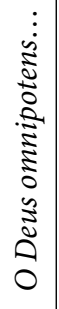 & 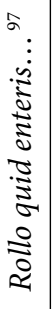 & 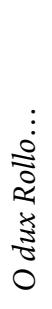 & 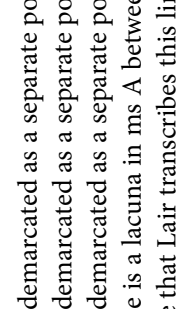 \\
\hline$\infty$ & $a$ & 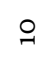 & 7 & $\approx$ & $\approx$ & \pm & $\approx$ & $\stackrel{9}{\nearrow}$ & 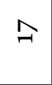 & $\stackrel{\infty}{\sim}$ & 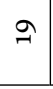 & $\stackrel{\text { i }}{ }$ & $a \sigma$ \\
\hline
\end{tabular}




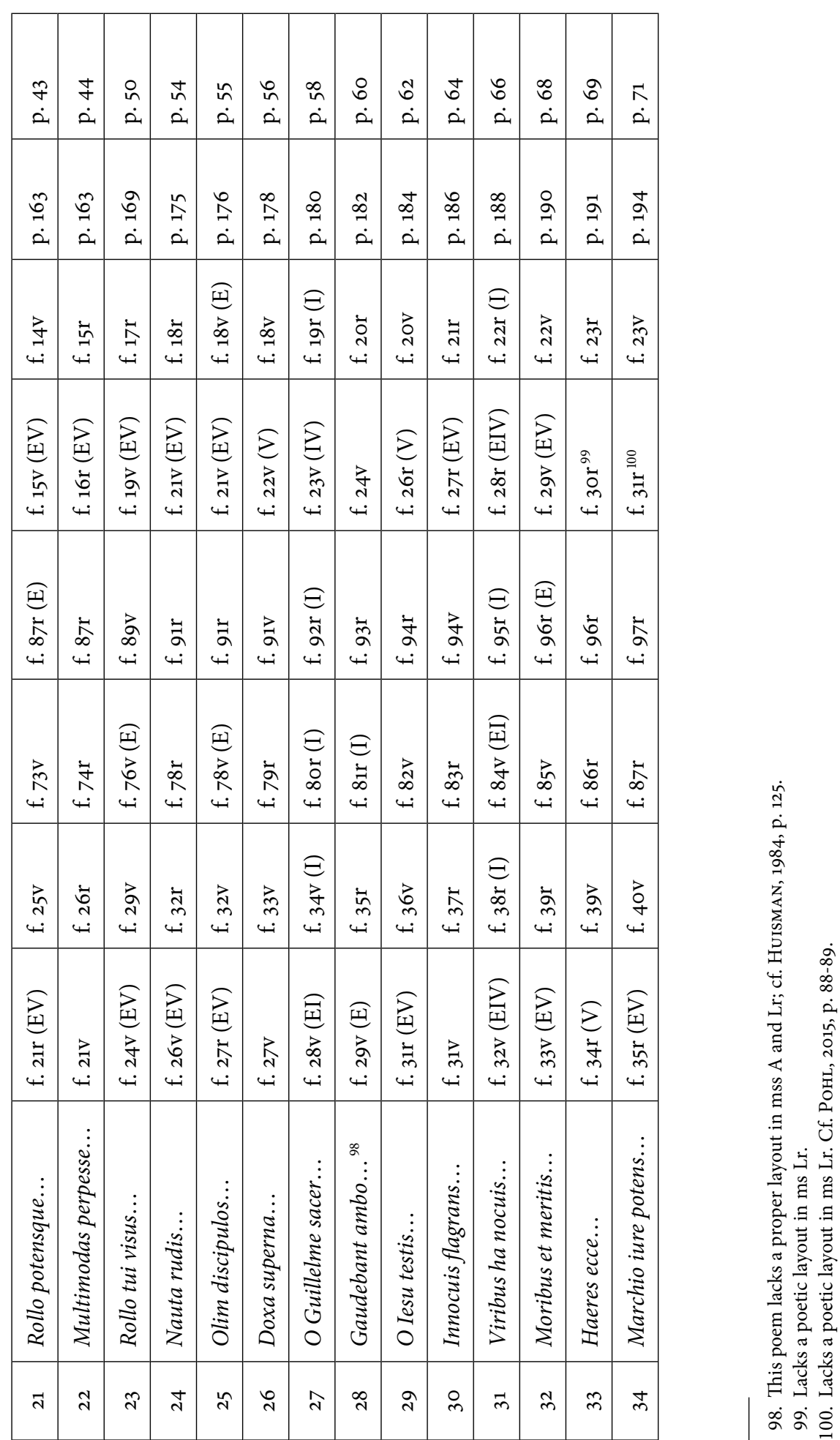

http://www.unicaen.fr/mrsh/craham/revue/tabularia/print.php?dossier=dossier15\&file=02pohl.xml 


\begin{tabular}{|c|c|c|c|c|c|c|c|c|c|c|c|c|c|c|}
\hline $\begin{array}{l}\stackrel{0}{\wedge} \\
\dot{\sim}\end{array}$ & $\begin{array}{l}\stackrel{0}{1} \\
\dot{n}\end{array}$ & 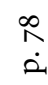 & $\begin{array}{l}\infty \\
\dot{\infty}\end{array}$ & $\begin{array}{l}+ \\
\infty \\
\dot{2}\end{array}$ & $\begin{array}{l}\dot{\infty} \\
\dot{2}\end{array}$ & $\begin{array}{l}\infty \\
\dot{2}\end{array}$ & $\begin{array}{l}\triangleright \\
\infty \\
\dot{2}\end{array}$ & $\begin{array}{l}\hat{\infty} \\
\dot{2}\end{array}$ & $\begin{array}{l}\hat{\alpha} \\
\dot{\alpha}\end{array}$ & $\begin{array}{l}\hat{\infty} \\
\dot{\alpha}\end{array}$ & $\begin{array}{l}\infty \\
\infty \\
\dot{2}\end{array}$ & $\begin{array}{l}\infty \\
\infty \\
\dot{2}\end{array}$ & $\begin{array}{l}\infty \\
\infty \\
\dot{2}\end{array}$ & $\begin{array}{l}\infty \\
\infty \\
\dot{2}\end{array}$ \\
\hline 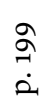 & $\begin{array}{l}\dot{0} \\
\dot{1} \\
\dot{2}\end{array}$ & $\begin{array}{l}\stackrel{N}{\text { d}} \\
\dot{\mathrm{d}}\end{array}$ & $\begin{array}{l}\stackrel{0}{0} \\
\stackrel{i}{0} \\
\dot{0}\end{array}$ & 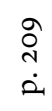 & $\begin{array}{l}0 \\
\text { ते } \\
\dot{\lambda}\end{array}$ & $\begin{array}{l}\stackrel{\circ}{\mathrm{n}} \\
\dot{\mathrm{n}}\end{array}$ & $\begin{array}{l}\text { ते } \\
\dot{\text { ¿ }}\end{array}$ & $\begin{array}{l}\vec{\lambda} \\
\dot{\lambda}\end{array}$ & $\begin{array}{l}\vec{\lambda} \\
\dot{\Delta}\end{array}$ & $\begin{array}{l}\text { ते } \\
\dot{\alpha}\end{array}$ & $\begin{array}{l}\vec{a} \\
\dot{d} \\
\dot{2}\end{array}$ & $\begin{array}{l}\vec{n} \\
\dot{a} \\
\dot{2}\end{array}$ & $\begin{array}{l}\vec{\Xi} \\
\vec{n} \\
\dot{\Delta} \\
\dot{\Delta}\end{array}$ & $\begin{array}{l}\vec{u} \\
\dot{\dot{n}}\end{array}$ \\
\hline 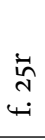 & $\begin{array}{r}\text { ते } \\
\text { ঙ }\end{array}$ & 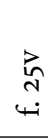 & $\begin{array}{r}\vec{N} \\
\stackrel{+}{*}\end{array}$ & 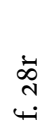 & 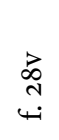 & 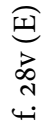 & 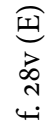 & 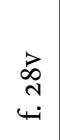 & 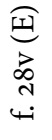 & 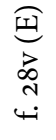 & 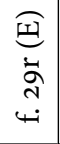 & $\underset{+}{\stackrel{\widehat{T}}{+}}$ & 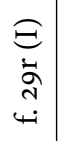 & 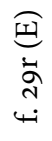 \\
\hline 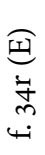 & 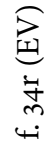 & $\begin{array}{l}\text { 空 } \\
\stackrel{5}{\omega} \\
\stackrel{4}{+}\end{array}$ & $\begin{array}{l}\mathcal{E} \\
\stackrel{\infty}{\infty} \\
\stackrel{m}{4}\end{array}$ & $\begin{array}{l}\vec{z} \\
\vec{m} \\
\vec{\omega} \\
\dot{4}\end{array}$ & 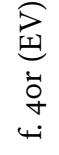 & 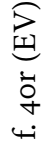 & $\begin{array}{l}E \\
\stackrel{E}{\sigma} \\
\stackrel{+}{+}\end{array}$ & $\begin{array}{l}\vec{z} \\
\vec{z} \\
\dot{+} \\
\dot{+}\end{array}$ & $\begin{array}{l}\vec{z} \\
\vec{b} \\
+ \\
+ \\
+\end{array}$ & 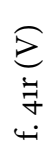 & $\begin{array}{l}\mathcal{E} \\
\stackrel{7}{7} \\
\stackrel{+}{i}\end{array}$ & 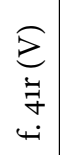 & 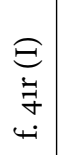 & $\stackrel{\overrightarrow{7}}{+}$ \\
\hline बूँ & ふ̆ & $\begin{array}{r}\overrightarrow{0} \\
\stackrel{0}{4}\end{array}$ & $\stackrel{?}{\stackrel{7}{\leftrightarrows}}$ & 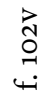 & & 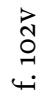 & $\stackrel{\text { Oे }}{\stackrel{0}{4}}$ & $\begin{array}{l}\overrightarrow{\tilde{O}} \\
\stackrel{4}{+}\end{array}$ & 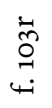 & $\stackrel{\stackrel{\tilde{\sigma}}{9}}{\stackrel{4}{4}}$ & $\begin{array}{l}\overrightarrow{\tilde{O}} \\
\stackrel{\vec{\psi}}{\dot{H}}\end{array}$ & $\stackrel{\overrightarrow{0}}{\stackrel{9}{4}}$ & $\begin{array}{l}\dot{\tilde{O}} \\
\stackrel{\leftrightarrow}{+}\end{array}$ & 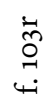 \\
\hline 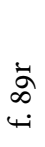 & $\begin{array}{c}\vec{\alpha} \\
\stackrel{\leftrightarrow}{+}\end{array}$ & aे & $\underset{\leftrightarrow}{\Delta}$ & 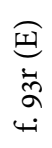 & 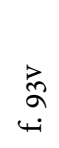 & 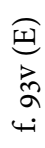 & $\vec{j}_{i}^{\vec{\alpha}}$ & 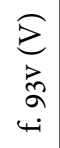 & 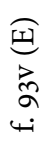 & $\underset{\dot{\psi}}{\overrightarrow{7}}$ & $\begin{array}{l}\overrightarrow{7} \\
\stackrel{7}{+}\end{array}$ & 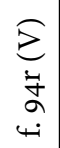 & 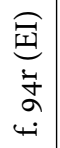 & 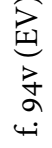 \\
\hline$\underset{+}{\vec{y}}$ & $\underset{4}{\vec{\gamma}}$ & $\underset{\leftarrow}{\vec{q}}$ & 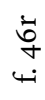 & $\underset{\leftarrow}{\vec{\gamma}}$ & $\underset{4}{\vec{\gamma}}$ & $\underset{+}{\stackrel{8}{+}}$ & $\underset{+}{\stackrel{8}{+}}$ & $\underset{+}{2}$ & \begin{tabular}{l} 
R \\
\multirow{4}{*}{}
\end{tabular} & $\begin{array}{l}8 \\
+ \\
+4\end{array}$ & 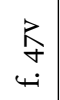 & $\begin{array}{l}R \\
+ \\
+4\end{array}$ & 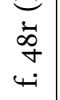 & 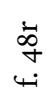 \\
\hline 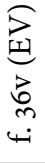 & 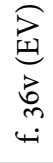 & 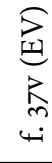 & $\begin{array}{l}\mathcal{E} \\
\dot{\exists} \\
\dot{\forall}\end{array}$ & 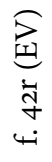 & 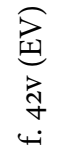 & 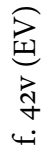 & 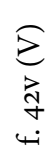 & $\underset{\leftrightarrow}{\vec{y}}$ & 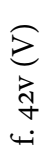 & 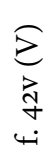 & $\begin{array}{l}E \\
\vec{u} \\
\vec{q} \\
\dot{q}\end{array}$ & $\stackrel{\vec{q}}{+}$ & 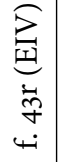 & 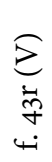 \\
\hline \begin{tabular}{l}
3 \\
\multirow{0}{0}{} \\
$\vdots$ \\
$\vdots$ \\
$\vdots$
\end{tabular} & 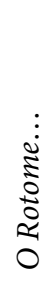 & 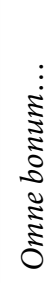 & 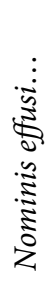 & 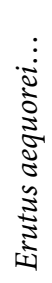 & $\begin{array}{l}\text { J } \\
0 \\
.0 \\
0 \\
0 \\
0 \\
0 \\
0 \\
0 \\
0\end{array}$ & 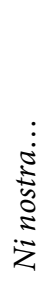 & 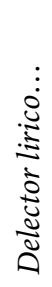 & 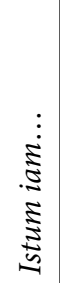 & 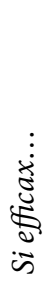 & 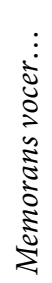 & 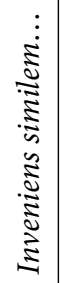 & 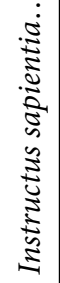 & 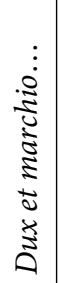 & 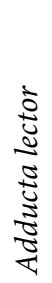 \\
\hline$\tilde{m}$ & d & $\hat{m}$ & $\stackrel{\infty}{\infty}$ & ले & $\stackrel{\circ}{+}$ & $F$ & $\mathcal{F}$ & $q$ & 字 & ஜ & $\stackrel{\circ}{+}$ & f & $\stackrel{\infty}{+}$ & $\vec{q}$ \\
\hline
\end{tabular}




\begin{tabular}{|c|c|c|c|c|c|c|c|c|c|c|c|c|}
\hline $\begin{array}{l}\stackrel{\infty}{ } \\
\stackrel{2}{2}\end{array}$ & $\begin{array}{l}\stackrel{\partial}{2} \\
\dot{2}\end{array}$ & $\begin{array}{l}\dot{\alpha} \\
\dot{2}\end{array}$ & $\begin{array}{l}\dot{2} \\
\dot{\dot{n}_{1}}\end{array}$ & $\begin{array}{l}\tilde{a} \\
\dot{2}\end{array}$ & $\begin{array}{l}\alpha \\
\dot{\dot{\alpha}}\end{array}$ & $\begin{array}{l}n \\
\dot{n} \\
\end{array}$ & $\begin{array}{l}n \\
\dot{n}\end{array}$ & $\begin{array}{l}\hat{\alpha} \\
\dot{\lambda}\end{array}$ & $\begin{array}{l}\infty \\
\vdots \\
\dot{2}\end{array}$ & $\begin{array}{l}\circ \\
\stackrel{1}{2} \\
\dot{2}\end{array}$ & $\begin{array}{l}\tilde{0} \\
\stackrel{\dot{\omega}}{1}\end{array}$ & $\begin{array}{l}\stackrel{+}{\circ} \\
\stackrel{\leftrightarrow}{\dot{a}}\end{array}$ \\
\hline $\begin{array}{l}\stackrel{\tilde{N}}{\text { n. }} \\
\dot{2}\end{array}$ & $\begin{array}{l}\dot{d} \\
\text { a } \\
\dot{2}\end{array}$ & $\begin{array}{l}\dot{U} \\
\dot{\lambda} \\
\dot{\lambda}\end{array}$ & $\begin{array}{l}\pi \\
\dot{\pi} \\
\dot{n} \\
\dot{n}\end{array}$ & $\begin{array}{l}\tilde{n} \\
\dot{n}\end{array}$ & 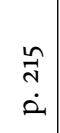 & $\begin{array}{l}\vec{\lambda} \\
\dot{n}\end{array}$ & $\begin{array}{l}\vec{\lambda} \\
\dot{\lambda}\end{array}$ & $\begin{array}{l}\vec{i} \\
\dot{n}\end{array}$ & $\begin{array}{l}\tilde{N} \\
\dot{\lambda} \\
\dot{2}\end{array}$ & 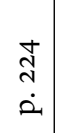 & 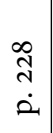 & $\begin{array}{l}\text { ते } \\
\text { ¿. }\end{array}$ \\
\hline 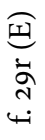 & $\underset{+}{\vec{T}}$ & $\underset{\sim}{\ddot{D}}$ & $\begin{array}{l}\overrightarrow{0} \\
\stackrel{्}{+}\end{array}$ & $\begin{array}{l}\overrightarrow{0} \\
\stackrel{्}{+}\end{array}$ & $\underset{\dot{m}}{\overrightarrow{0}}$ & 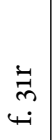 & $\underset{m}{\vec{m}}$ & $\begin{array}{l}\vec{d} \\
\stackrel{\sim}{+}\end{array}$ & $\begin{array}{l}\overrightarrow{\mathrm{m}} \\
\stackrel{i}{i}\end{array}$ & $\underset{\stackrel{m}{m}}{\stackrel{\vec{i}}{i}}$ & 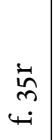 & $\begin{array}{l}\Theta \\
\stackrel{ \pm}{0} \\
\stackrel{\oplus}{+}\end{array}$ \\
\hline 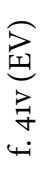 & 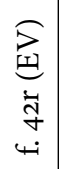 & 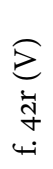 & 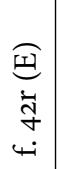 & 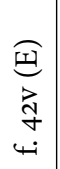 & 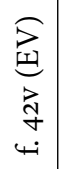 & 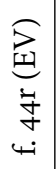 & $\begin{array}{c}\widetilde{⿶} \\
\breve{y} \\
\stackrel{+}{+}\end{array}$ & $\begin{array}{c}\dot{y} \\
\dot{q} \\
\dot{t}\end{array}$ & $\begin{array}{l}\vec{Z} \\
\stackrel{0}{0} \\
\stackrel{4}{+}\end{array}$ & $\begin{array}{c}\overrightarrow{5} \\
\dot{y} \\
\dot{H}\end{array}$ & $\begin{array}{l}E \\
\vec{a} \\
\vec{g} \\
\stackrel{+}{i}\end{array}$ & \begin{tabular}{l}
$\underset{z}{\Xi}$ \\
\multirow{2}{n}{} \\
$\dot{w}$
\end{tabular} \\
\hline 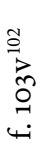 & $\begin{array}{l}\overrightarrow{\tilde{O}} \\
\stackrel{\leftrightarrow}{+}\end{array}$ & $\begin{array}{l}\overrightarrow{0} \\
\stackrel{0}{4} \\
\end{array}$ & 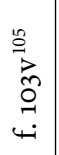 & $\begin{array}{l}\overrightarrow{7} \\
0 \\
-7 \\
\dot{H}\end{array}$ & 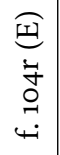 & 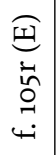 & $\begin{array}{l}\dot{\hat{n}} \\
\stackrel{+}{+} \\
\dot{H}\end{array}$ & 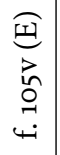 & $\begin{array}{l}\stackrel{ \pm}{0} \\
\stackrel{1}{4} \\
\dot{4}\end{array}$ & $\begin{array}{l}\vec{b} \\
0 \\
\rightarrow \\
\dot{4}\end{array}$ & $\begin{array}{l}\dot{0} \\
0 \\
\stackrel{+}{+}\end{array}$ & 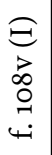 \\
\hline 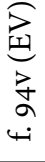 & 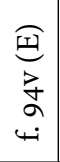 & $\stackrel{\dot{\omega n}}{\stackrel{n}{\alpha}}$ & 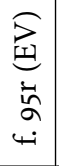 & $\begin{array}{l}\vec{h} \\
\stackrel{\leftrightarrow}{+}\end{array}$ & 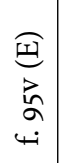 & $\begin{array}{l}\vec{b} \\
a \\
\dot{4}\end{array}$ & 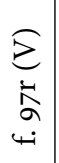 & $\begin{array}{l}R \\
\alpha \\
\rightarrow i\end{array}$ & $\begin{array}{l}\vec{D} \\
\alpha \\
\dot{H}\end{array}$ & $\begin{array}{l}\vec{a} \\
\dot{\leftrightarrow}\end{array}$ & $\underset{+}{\stackrel{ \pm}{0}}$ & 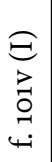 \\
\hline 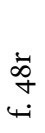 & 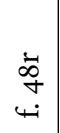 & 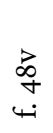 & 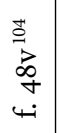 & $\begin{array}{l}\overrightarrow{0} \\
\stackrel{0}{+} \\
\stackrel{+}{+}\end{array}$ & $\begin{array}{l}\vec{b} \\
\stackrel{0}{+} \\
\stackrel{+}{+}\end{array}$ & $\begin{array}{l}\overrightarrow{0} \\
\dot{n} \\
\dot{H}\end{array}$ & 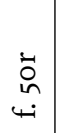 & 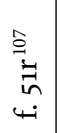 & 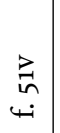 & $\begin{array}{l}\dot{\hat{N}} \\
\stackrel{H}{*}\end{array}$ & 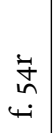 & 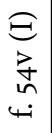 \\
\hline 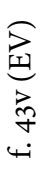 & 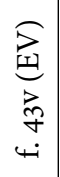 & \begin{tabular}{l}
$\mathcal{E}$ \\
$\vec{j}$ \\
$\dot{q}$ \\
\multirow{4}{*}{}
\end{tabular} & 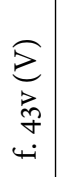 & 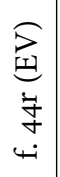 & 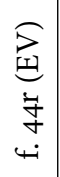 & 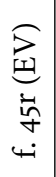 & 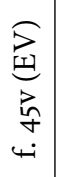 & $\begin{array}{c}\mathbb{E} \\
\overleftarrow{b} \\
\dot{t} \\
\stackrel{+}{*}\end{array}$ & 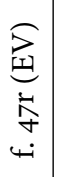 & 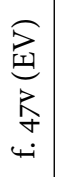 & $\begin{array}{l}\mathcal{E} \\
\dot{0} \\
+ \\
+i\end{array}$ & 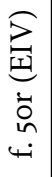 \\
\hline 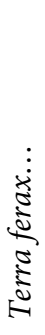 & 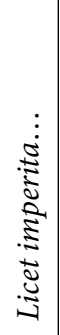 & 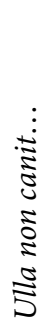 & 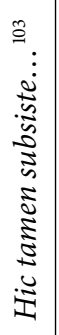 & 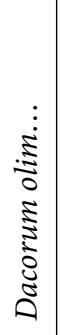 & 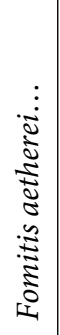 & 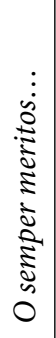 & 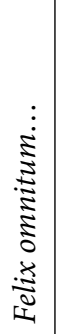 & 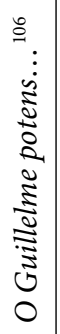 & 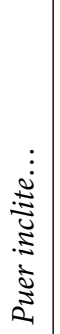 & 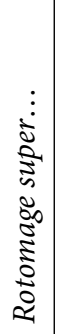 & 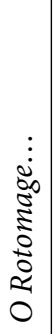 & 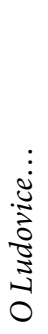 \\
\hline in & $\vec{n}$ & in & $\hat{n}$ & in & in & in & in & in & in & $\circ$ & $\vec{\sigma}$ & న్ \\
\hline
\end{tabular}




\begin{tabular}{|c|c|c|c|c|c|c|c|c|c|c|c|c|c|c|}
\hline $\begin{array}{l}\stackrel{0}{\circ} \\
\stackrel{2}{2}\end{array}$ & $\begin{array}{l}\infty \\
0 \\
\stackrel{0}{2} \\
\dot{n}\end{array}$ & $\stackrel{0}{\stackrel{2}{2}}$ & $\begin{array}{l}\mathcal{M} \\
\dot{2}\end{array}$ & $\vec{a}$ & 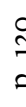 & 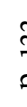 & & & & 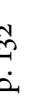 & 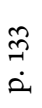 & $\begin{array}{l}\stackrel{m}{2} \\
\stackrel{2}{2}\end{array}$ & $\stackrel{m}{\stackrel{2}{2}}$ & \\
\hline $\begin{array}{l}\vec{i} \\
\dot{2}\end{array}$ & $\begin{array}{l}\tilde{\sim} \\
\dot{\imath} \\
\dot{2}\end{array}$ & $\begin{array}{l}\stackrel{\tilde{d}}{\grave{d}} \\
\dot{n}\end{array}$ & 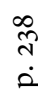 & 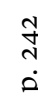 & 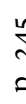 & 0 & & & & م. & 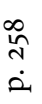 & $\begin{array}{l}\stackrel{\hat{a}}{\text { an }} \\
\text { an }\end{array}$ & $\begin{array}{l}\text { ì } \\
\stackrel{0}{\circ}\end{array}$ & 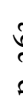 \\
\hline 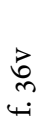 & 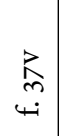 & 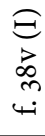 & بَّ & $\stackrel{4}{4}$ & 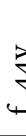 & 4 & 1 & & & 客 & $\begin{array}{l}E \\
\vec{a} \\
\vec{a} \\
\overrightarrow{4} \\
\dot{4}\end{array}$ & 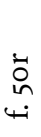 & $\stackrel{\overrightarrow{0}}{\stackrel{4}{n}}$ & \\
\hline 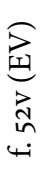 & 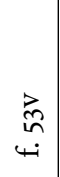 & 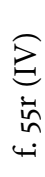 & 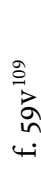 & $\stackrel{\vec{\sigma}}{*}$ & 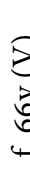 & 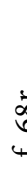 & E & & & 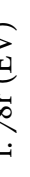 & 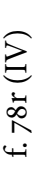 & 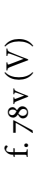 & 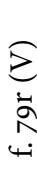 & \\
\hline $\begin{array}{l}\overrightarrow{\hat{o}} \\
\stackrel{\leftrightarrow}{4}\end{array}$ & 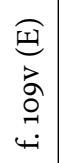 & 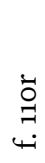 & 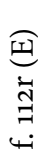 & 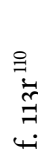 & 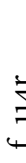 & 7 & $\hat{B}$ & & & 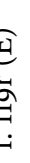 & 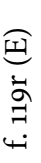 & $\underset{\sim}{\vec{\exists}}$ & $\overrightarrow{7}$ & \\
\hline 总 & $\begin{array}{r}\overrightarrow{0} \\
\stackrel{0}{+} \\
\end{array}$ & 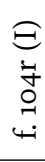 & 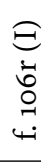 & $\stackrel{?}{3}$ & 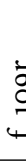 & 4 & 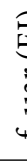 & & & $\vec{t}$ & 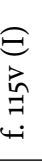 & 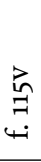 & $\stackrel{ \pm}{ \pm}$ & \\
\hline 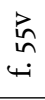 & $\begin{array}{l}\overrightarrow{0} \\
\stackrel{0}{n} \\
\dot{4}\end{array}$ & 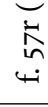 & 离 & $\underset{+}{8}$ & $\tilde{\sigma}$ & 4 & 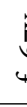 & & & $\begin{array}{l}5 \\
i \\
\end{array}$ & 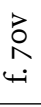 & $\begin{array}{r}3 \\
\\
4 \\
\end{array}$ & $\underset{4}{*}$ & \\
\hline 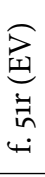 & 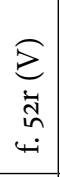 & 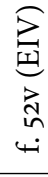 & 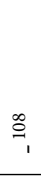 & ' & ' & & & & & & 1 & ' & & \\
\hline 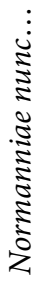 & 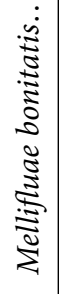 & 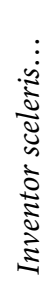 & ؛े & ปี & c. & $=$ & & & & & 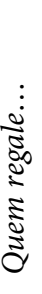 & 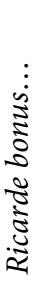 & 苗 & 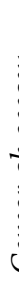 \\
\hline$\tilde{0}$ & ర్ & $\tilde{b}$ & o & 6 & 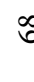 & 6 & & & & N & $\Re$ & $\stackrel{+}{\wedge}$ & N & 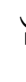 \\
\hline
\end{tabular}




\begin{tabular}{|c|c|c|c|c|c|c|c|c|c|c|c|c|c|c|c|}
\hline 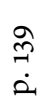 & 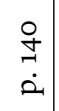 & $\begin{array}{l}\mathcal{J} \\
\dot{\mathrm{d}}\end{array}$ & $\begin{array}{l}\frac{J}{ \pm} \\
\dot{2}\end{array}$ & $\begin{array}{l}\text { fq } \\
\dot{2}\end{array}$ & $\begin{array}{l}\text { fे } \\
\dot{2}\end{array}$ & 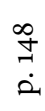 & $\begin{array}{l}\stackrel{g}{\mathrm{~d}} \\
\dot{\mathrm{i}}\end{array}$ & $\stackrel{\circ}{\stackrel{2}{2}}$ & $\begin{array}{l}\stackrel{+}{\prime} \\
\stackrel{2}{2}\end{array}$ & $\begin{array}{l}\tilde{0} \\
\dot{\Delta} \\
\end{array}$ & $\begin{array}{l}\stackrel{\bullet}{0} \\
\stackrel{\dot{n}}{2}\end{array}$ & $\begin{array}{l}\stackrel{0}{1} \\
\dot{\Delta}\end{array}$ & $\begin{array}{l}\tilde{n} \\
\dot{\Delta}\end{array}$ & $\begin{array}{l}\stackrel{+}{\hat{L}} \\
\dot{2}\end{array}$ & \\
\hline 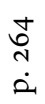 & 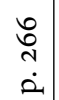 & $\begin{array}{l}\infty \\
\stackrel{0}{0} \\
\stackrel{2}{2}\end{array}$ & $\begin{array}{l}\text { aे } \\
\dot{1} \\
\dot{2}\end{array}$ & $\begin{array}{l}\stackrel{0}{\hat{~}} \\
\dot{2}\end{array}$ & $\begin{array}{l}\hat{\sim} \\
\dot{\alpha}\end{array}$ & $\begin{array}{l}\stackrel{+}{+} \\
\dot{2}\end{array}$ & $\begin{array}{l}\stackrel{n}{n} \\
\dot{\alpha}\end{array}$ & $\begin{array}{l}\stackrel{0}{\Lambda} \\
\dot{\lambda}\end{array}$ & 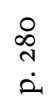 & $\begin{array}{l}\infty \\
0 \\
1 \\
\dot{\alpha}\end{array}$ & $\begin{array}{l}\tilde{\mathrm{d}} \\
\dot{\mathrm{c}}\end{array}$ & 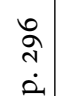 & $\begin{array}{l}\stackrel{\mathrm{d}}{\mathrm{c}} \\
\dot{\mathrm{c}}\end{array}$ & $\begin{array}{l}\stackrel{0}{0} \\
\dot{m} \\
\dot{\alpha}\end{array}$ & \\
\hline 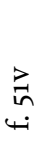 & 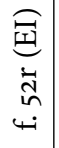 & $\stackrel{\vec{\sim}}{\stackrel{i}{*}}$ & 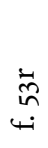 & 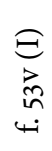 & 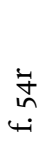 & 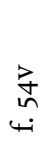 & $\underset{\leftrightarrow}{\stackrel{\vec{n}}{n}}$ & 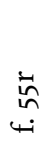 & $\underset{\leftrightarrow}{\stackrel{B}{:}}$ & $\begin{array}{l}\vec{a} \\
\stackrel{n}{i}\end{array}$ & $\begin{array}{l}\vec{\theta} \\
\vec{b} \\
\stackrel{0}{+} \\
\Psi\end{array}$ & $\begin{array}{l}\vec{Z} \\
\stackrel{\leftrightarrow}{+}\end{array}$ & $\begin{array}{l}\dot{\hat{\theta}} \\
\stackrel{+}{+}\end{array}$ & 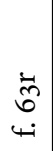 & $\infty^{\infty}$ \\
\hline 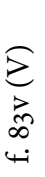 & 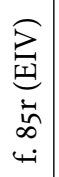 & 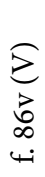 & 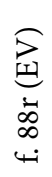 & 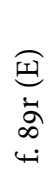 & 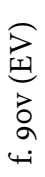 & 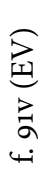 & 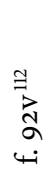 & 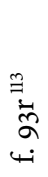 & 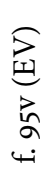 & 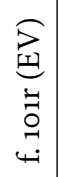 & 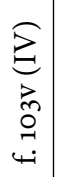 & 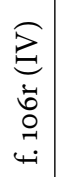 & 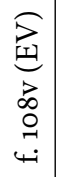 & 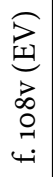 & $\vec{j}$ \\
\hline 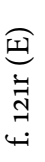 & 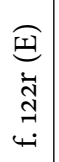 & $\underset{\sim}{\vec{J}}$ & 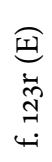 & $\underset{\widetilde{\widetilde{T}}}{\vec{\Psi}}$ & 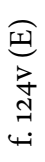 & 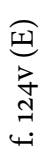 & 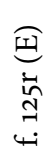 & 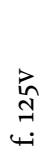 & 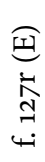 & 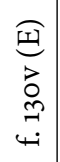 & $\begin{array}{l}\vec{\Xi} \\
\vec{J} \\
\stackrel{\oplus}{\Psi}\end{array}$ & 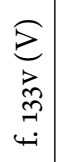 & 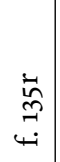 & $\begin{array}{l}\overrightarrow{\tilde{\sigma}} \\
\stackrel{\leftrightarrow}{\Psi}\end{array}$ & $\bar{\Xi}$ \\
\hline 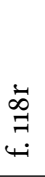 & 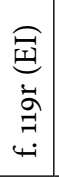 & 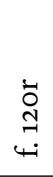 & 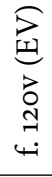 & 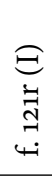 & 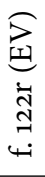 & 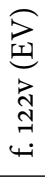 & 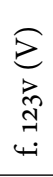 & 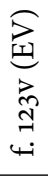 & 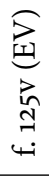 & $\begin{array}{r}\overrightarrow{0} \\
\stackrel{0}{*} \\
\dot{\Psi}\end{array}$ & 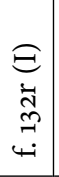 & $\begin{array}{l}\mathbb{E} \\
\stackrel{m}{m} \\
\stackrel{\oplus}{+}\end{array}$ & $\stackrel{\#}{\#}$ & ' & 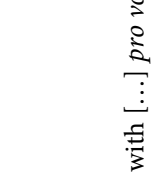 \\
\hline 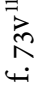 & $\begin{array}{l}7 \\
\stackrel{7}{4} \\
\rightarrow\end{array}$ & 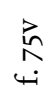 & $\begin{array}{l}\stackrel{\vec{D}}{\wedge} \\
\stackrel{4}{4}\end{array}$ & \begin{tabular}{l}
$\vec{b}$ \\
$\stackrel{1}{4}$ \\
\multirow{4}{*}{}
\end{tabular} & 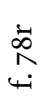 & $\begin{array}{c}\stackrel{b}{\wedge} \\
\stackrel{+}{+}\end{array}$ & 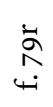 & $\stackrel{2}{2}$ & $\begin{array}{l}\vec{D} \\
\infty \\
4 \\
\end{array}$ & $\begin{array}{c}\overrightarrow{1} \\
\infty \\
+ \\
\end{array}$ & $\begin{array}{c}\overrightarrow{\widehat{\sigma}} \\
\infty \\
+\end{array}$ & $\begin{array}{l}\vec{z} \\
\leftrightarrow \\
\leftrightarrow\end{array}$ & $\begin{array}{c}\dot{\tilde{\sigma}} \\
\dot{\leftrightarrow}\end{array}$ & $\begin{array}{l}\dot{\sigma} \\
\dot{\sigma}\end{array}$ & \\
\hline , & ' & ' & . & , & ' & , & , & , & , & . & , & , & , & , & \\
\hline 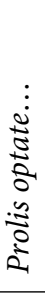 & 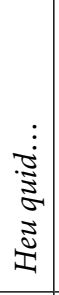 & 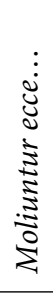 & 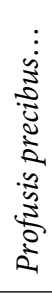 & 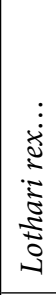 & 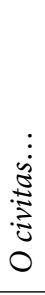 & 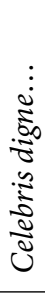 & 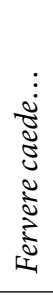 & 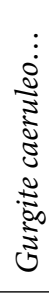 & 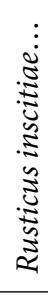 & 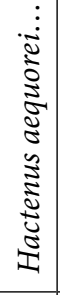 & 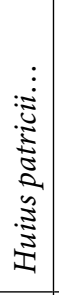 & 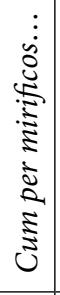 & 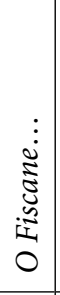 & $\begin{array}{l}3 \\
\vdots \\
0 \\
0\end{array}$ & 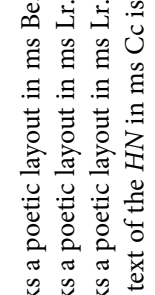 \\
\hline 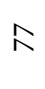 & $\stackrel{\infty}{\wedge}$ & શ & $\infty$ & $\vec{\infty}$ & $\infty$ & $\infty$ & ాే & $\stackrel{\infty}{\infty}$ & $\infty$ & $\infty$ & $\stackrel{\infty}{\infty}$ & ळ) & ஃ & $\bar{\sigma}$ & \\
\hline
\end{tabular}




\section{Appendix 2: Graphs}

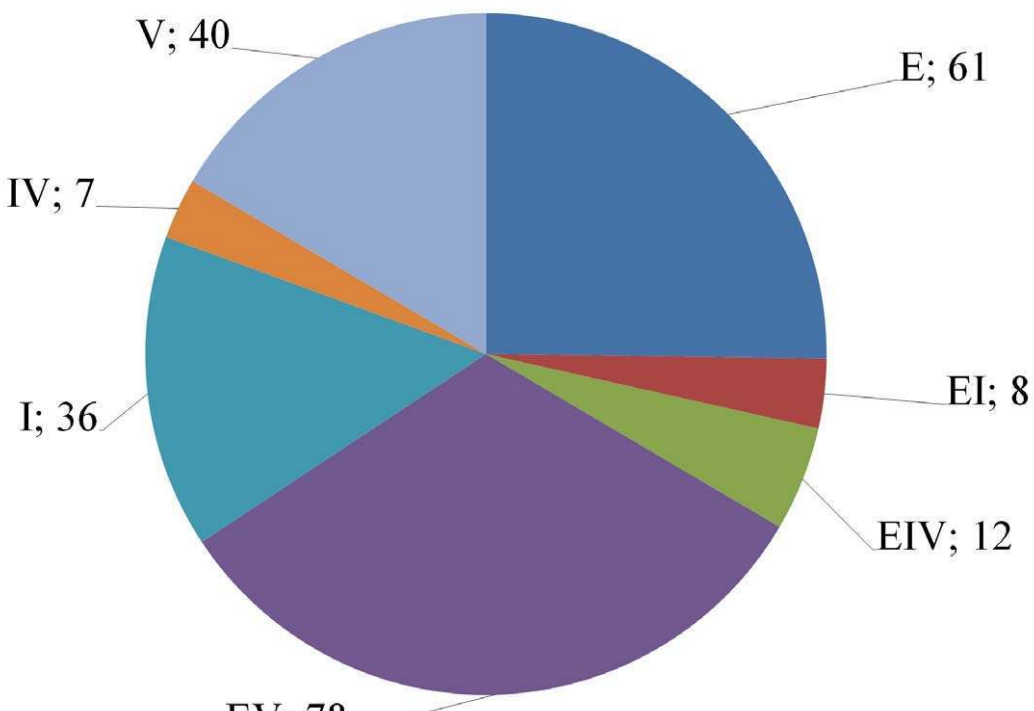

$\mathrm{EV} ; 78$

Graph 1: Total number of poems exhibiting punctus elevatus (E), punctus interrogativus (I) and punctus versus (V)

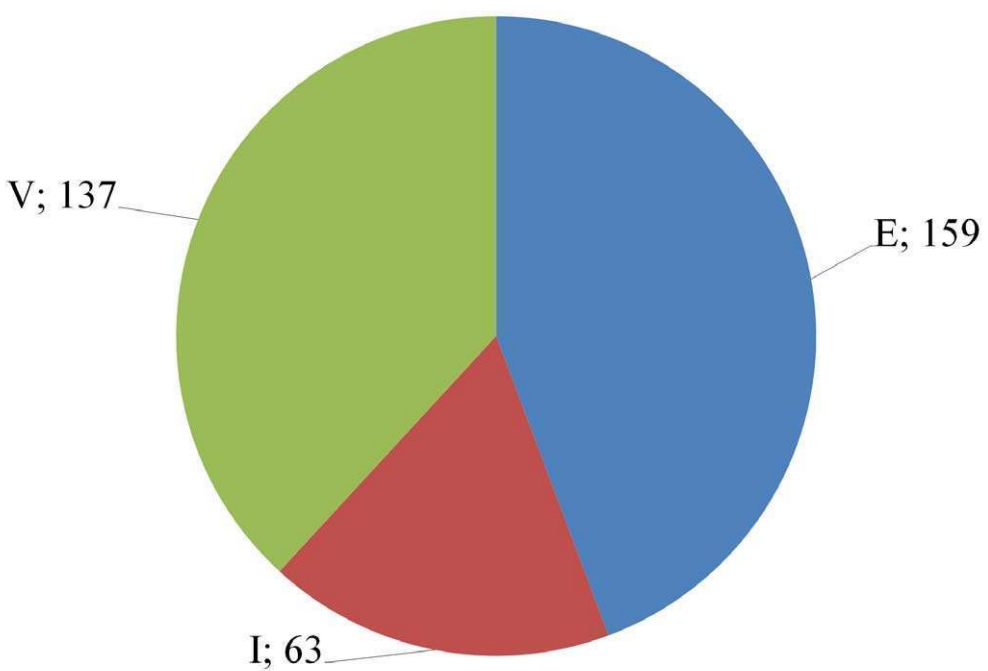

Graph 2: Total number of poems exhibiting combinations of positurae 


\section{Figures}

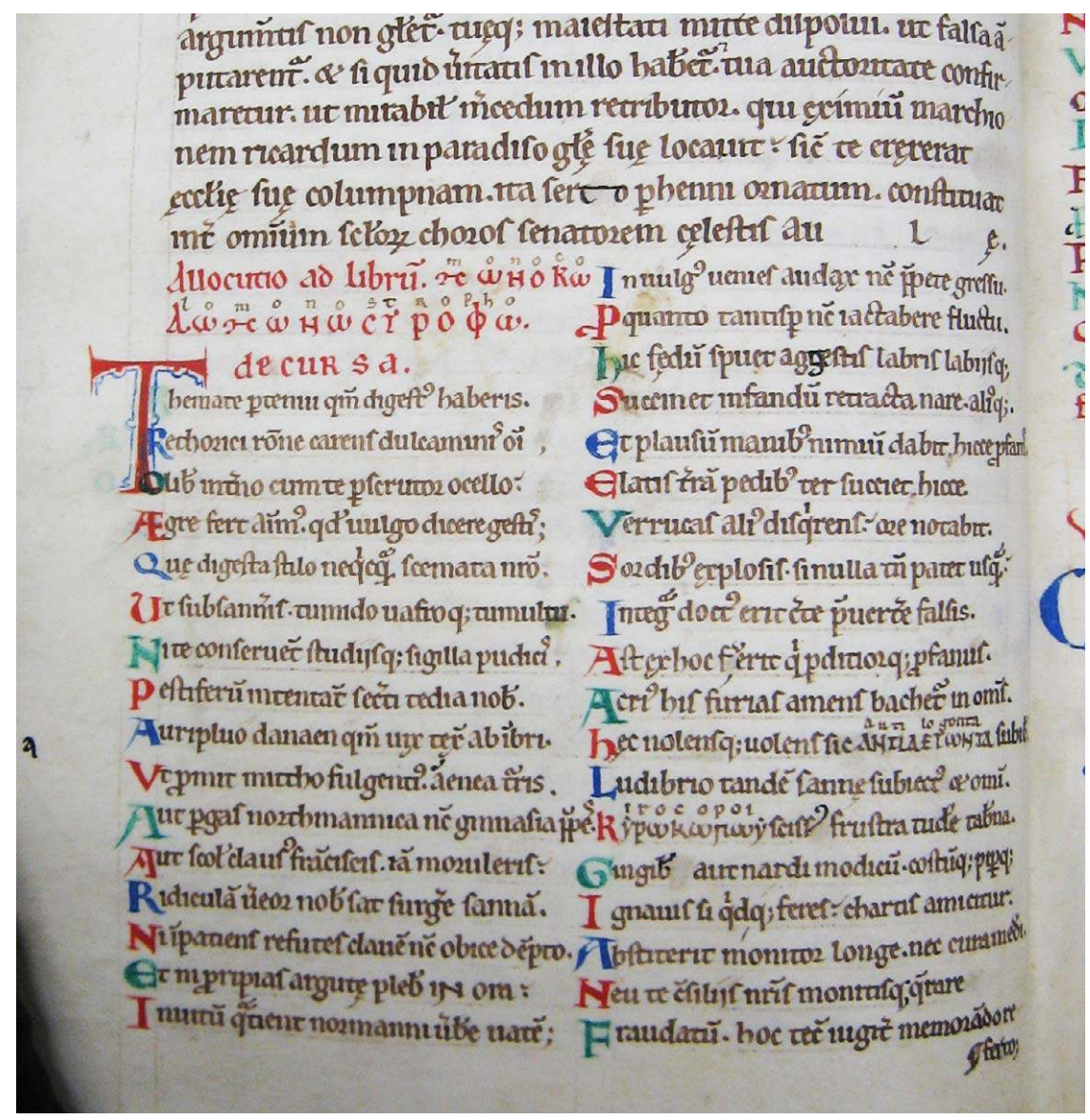

Fig. 1: Antwerp, Museum Plantin-Moretus/Prentenkabinet, ms 17.2, fol. 3v (detail). Reproduced by kind permission of the Museum Plantin-Moretus/Prentenkabinet, UNESCO - World Heritage, Antwerp 


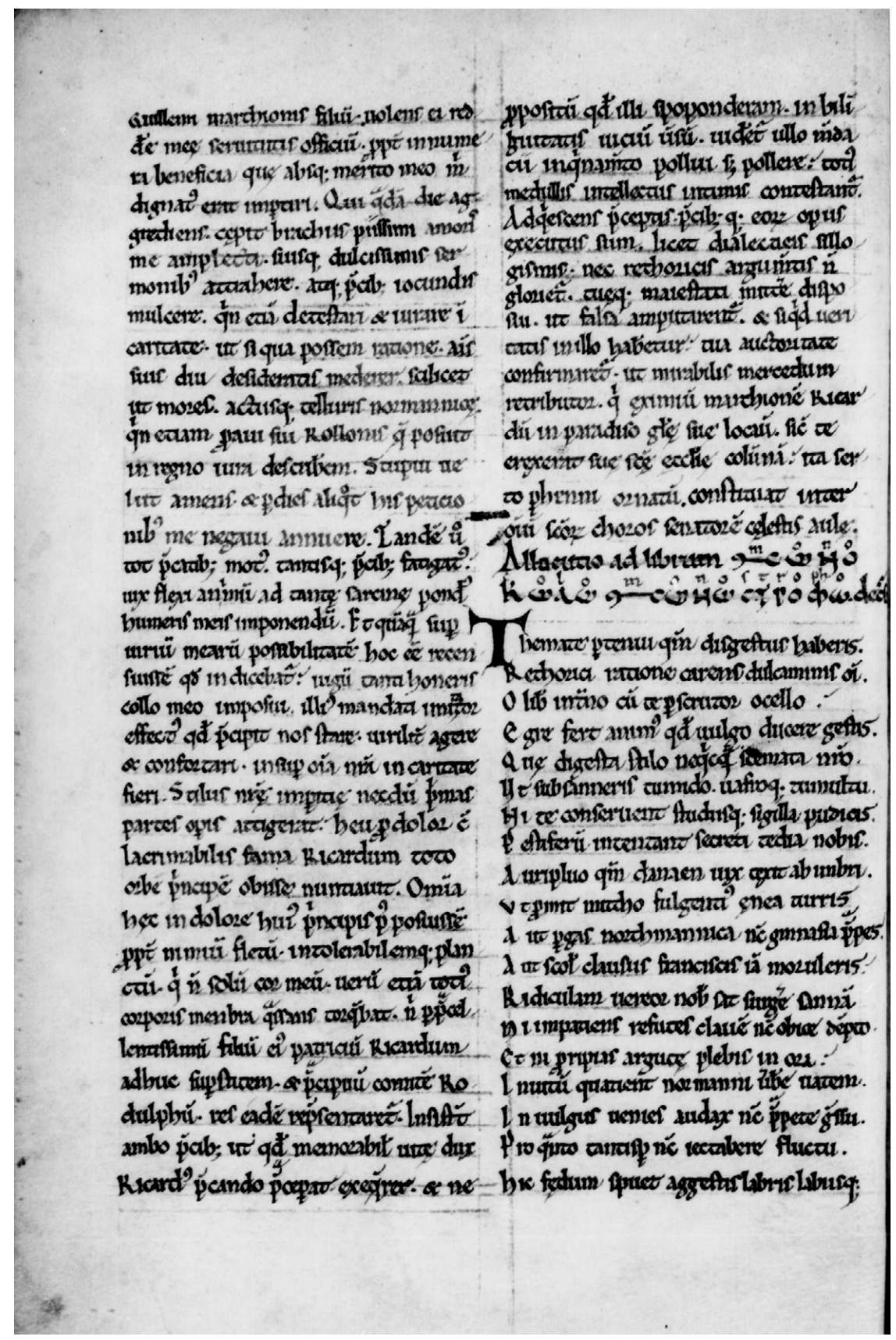

Fig. 2: London, British Library, ms Royal 13 B xiv, fol. 2v

(c) The British Library Board 


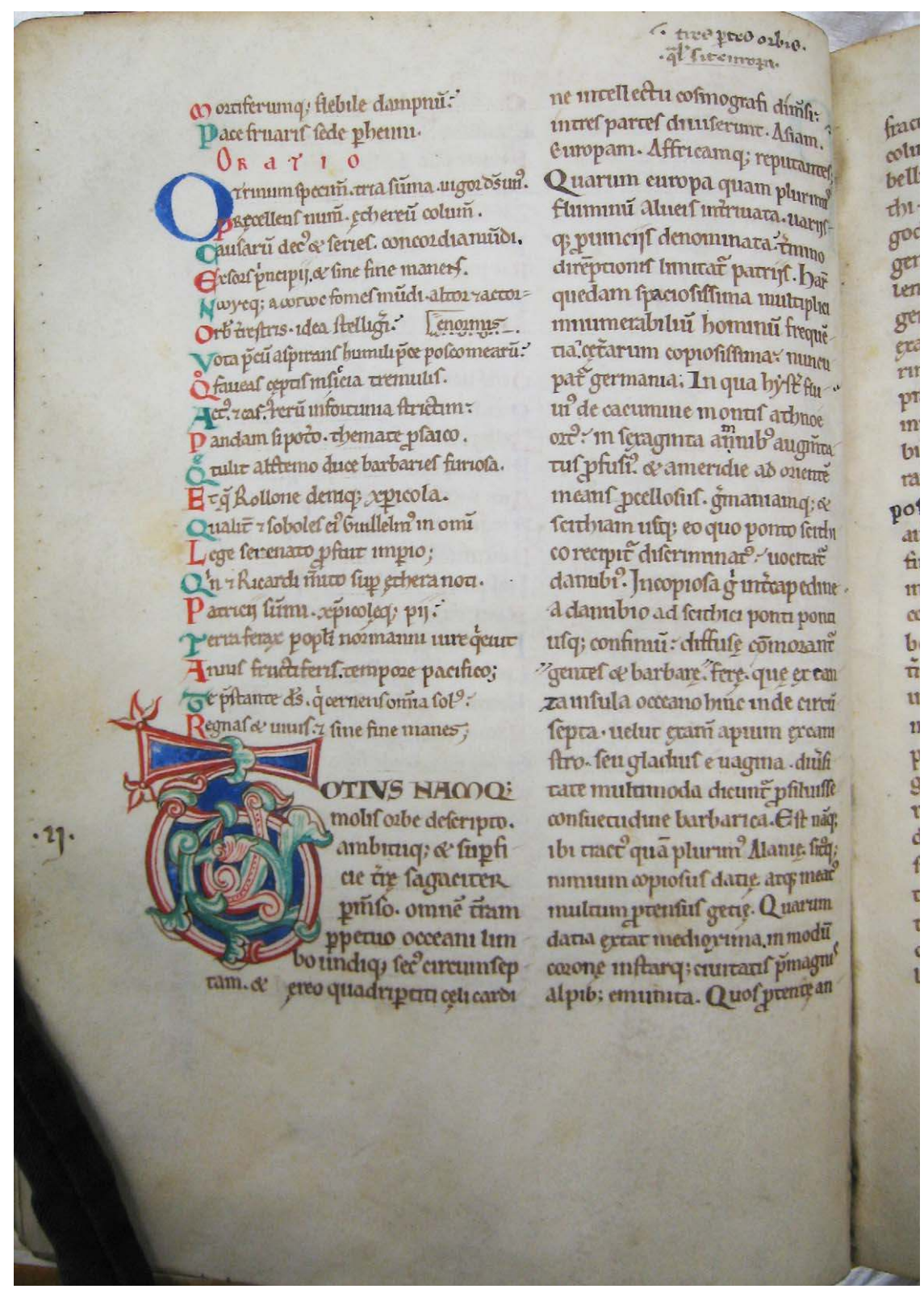

Fig. 3: Antwerp, Museum Plantin-Moretus/Prentenkabinet, ms 17.2, fol. 6v. Reproduced by kind permission of the Museum Plantin-Moretus/Prentenkabinet, UNESCO - World Heritage, Antwerp 


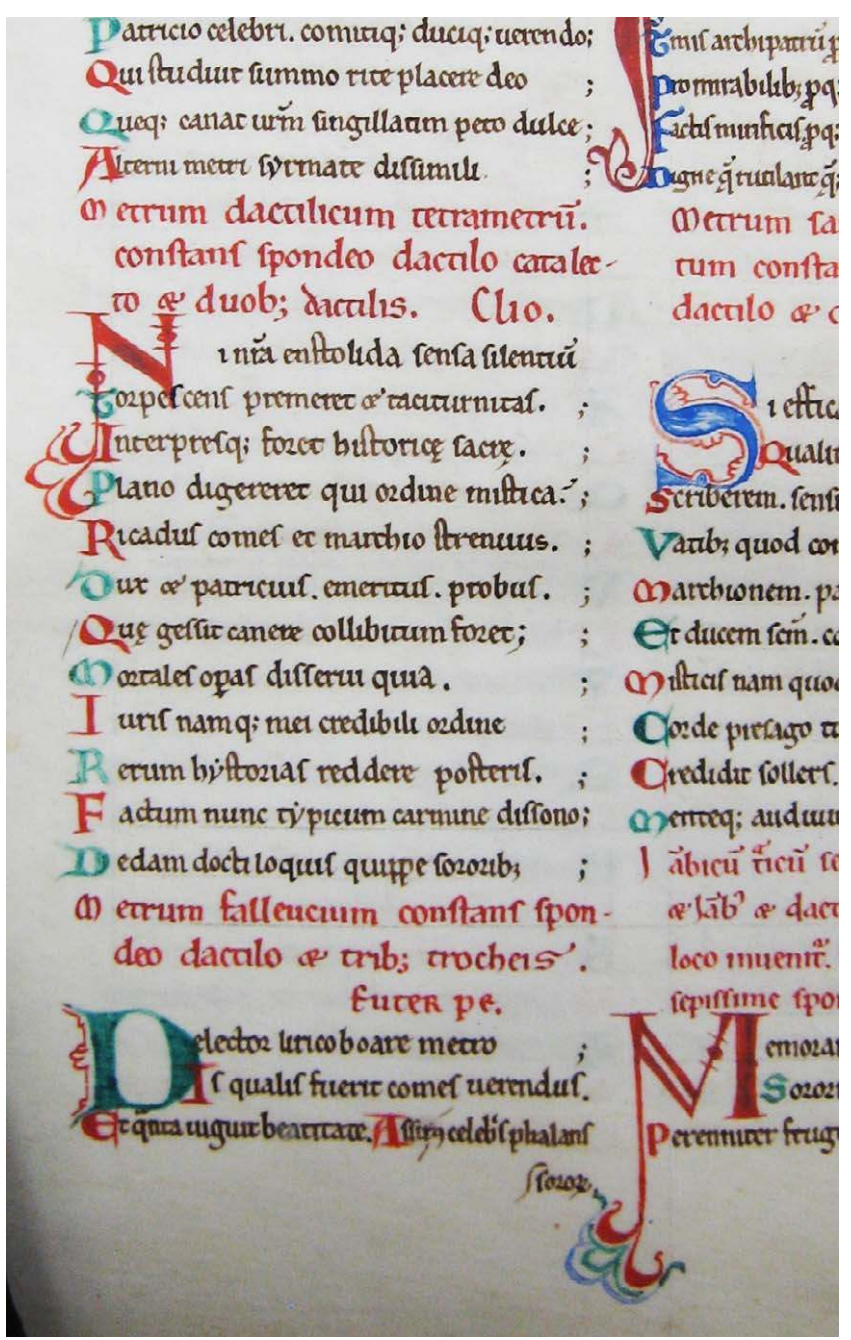

Fig. 4: Antwerp, Museum Plantin-Moretus/Prentenkabinet, ms 17.2, fol. 42v (detail). Reproduced by kind permission of the Museum Plantin-Moretus/Prentenkabinet, UNESCO - World Heritage, Antwerp 


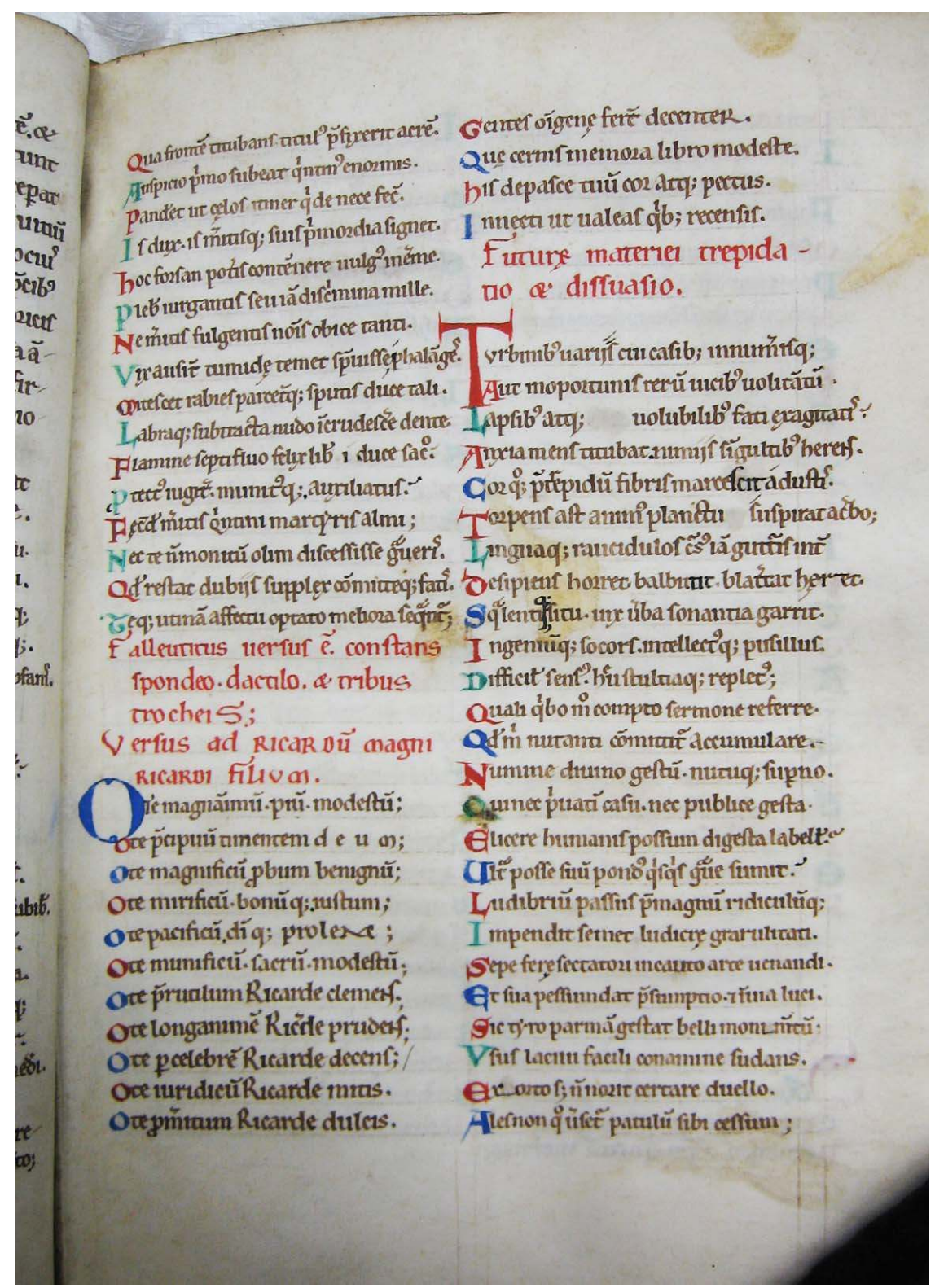

Fig. 5: Antwerp, Museum Plantin-Moretus/Prentenkabinet, ms 17.2, fol. 4r. Reproduced by kind permission of the Museum Plantin-Moretus/Prentenkabinet, UNESCO - World Heritage, Antwerp 


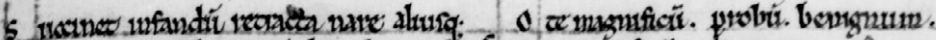

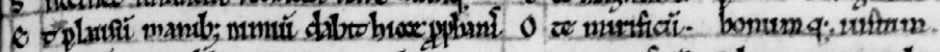

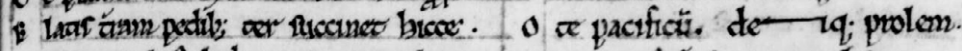

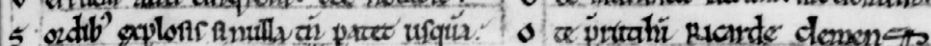

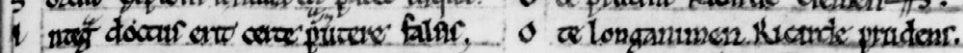

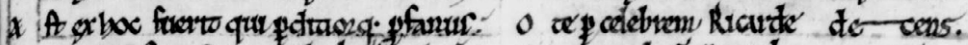

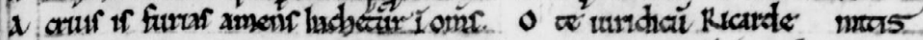

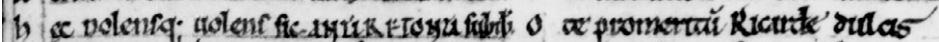

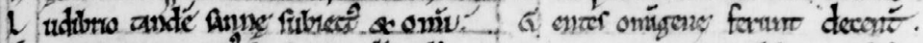

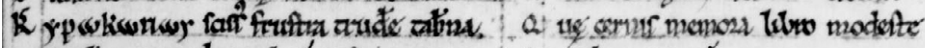

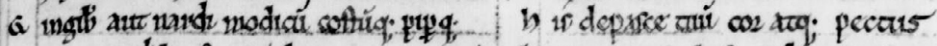

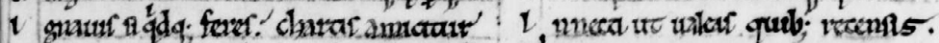

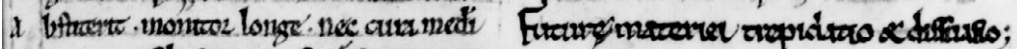

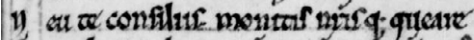

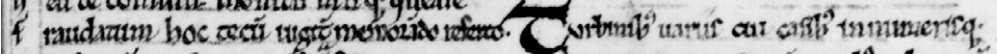

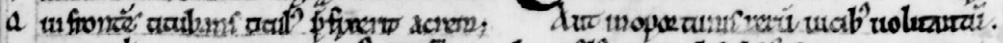

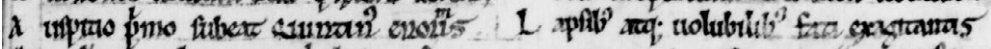

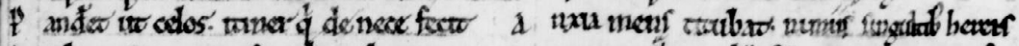

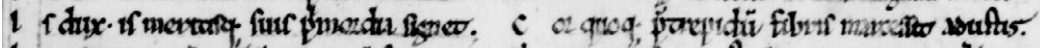

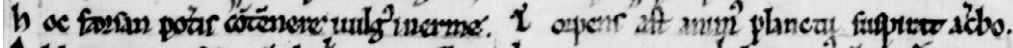

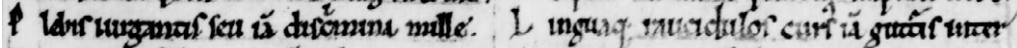

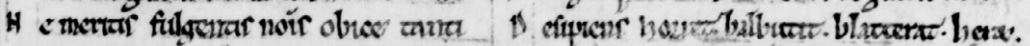

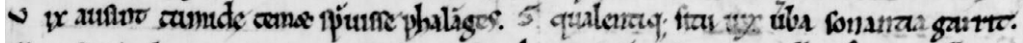

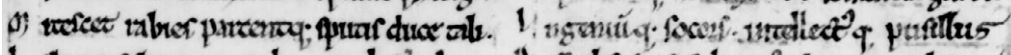

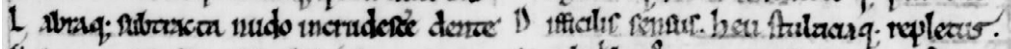

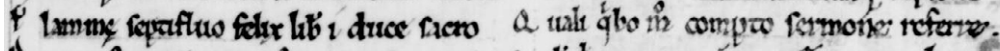

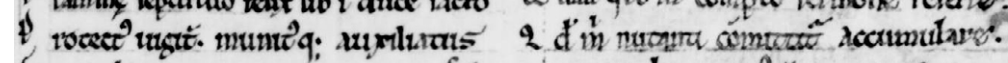

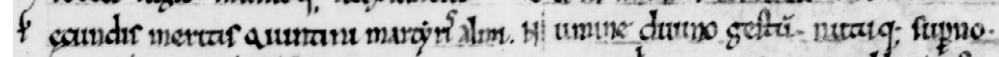

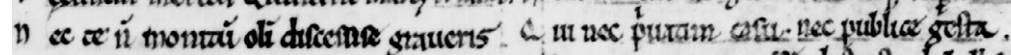

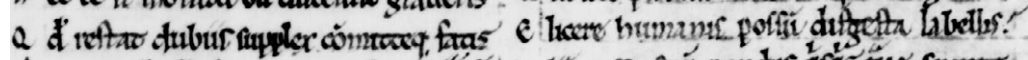

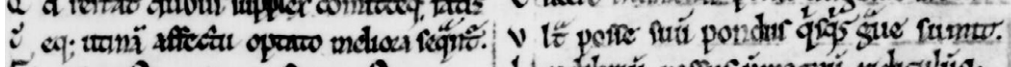

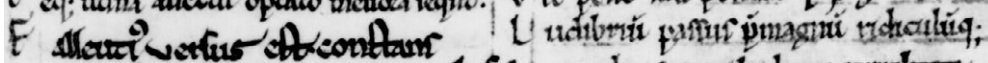

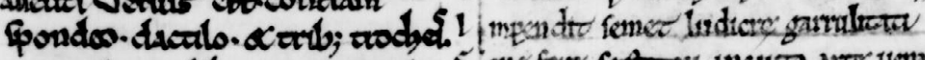

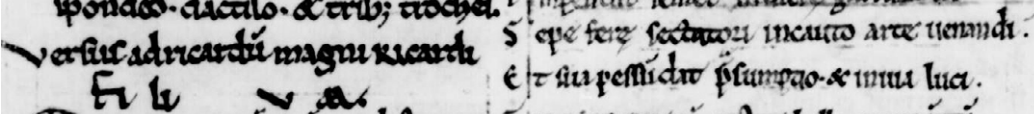

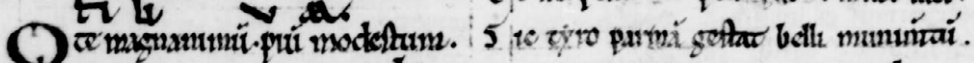

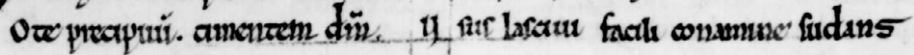

Fig. 6: London, British Library, ms Royal 13 B xiv, fol. $3 r$

(C) The British Library Board 


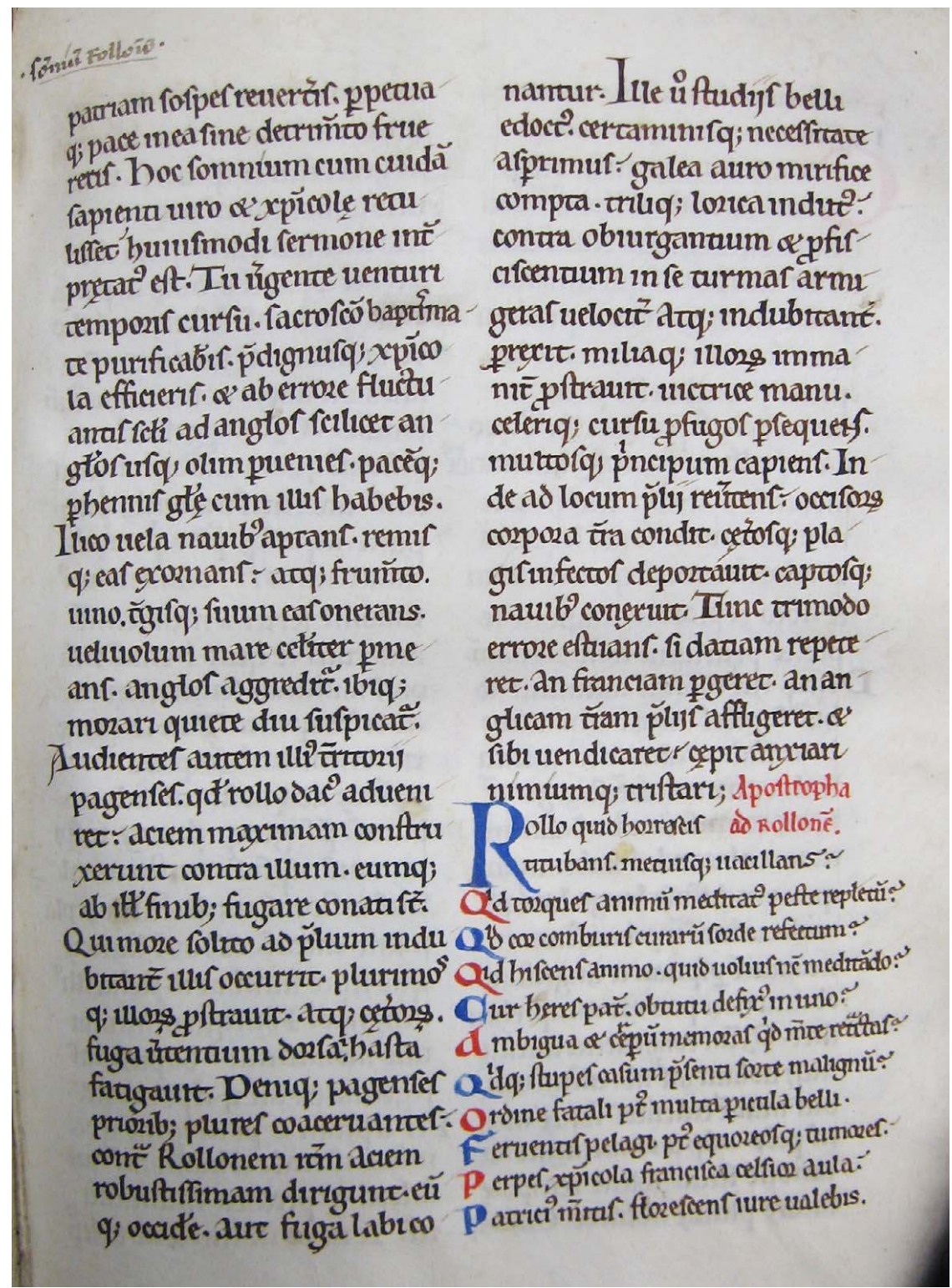

Fig. 7: Antwerp, Museum Plantin-Moretus/Prentenkabinet, ms 17.2, fol. 14r. Reproduced by kind permission of the Museum Plantin-Moretus/Prentenkabinet, UNESCO - World Heritage, Antwerp 


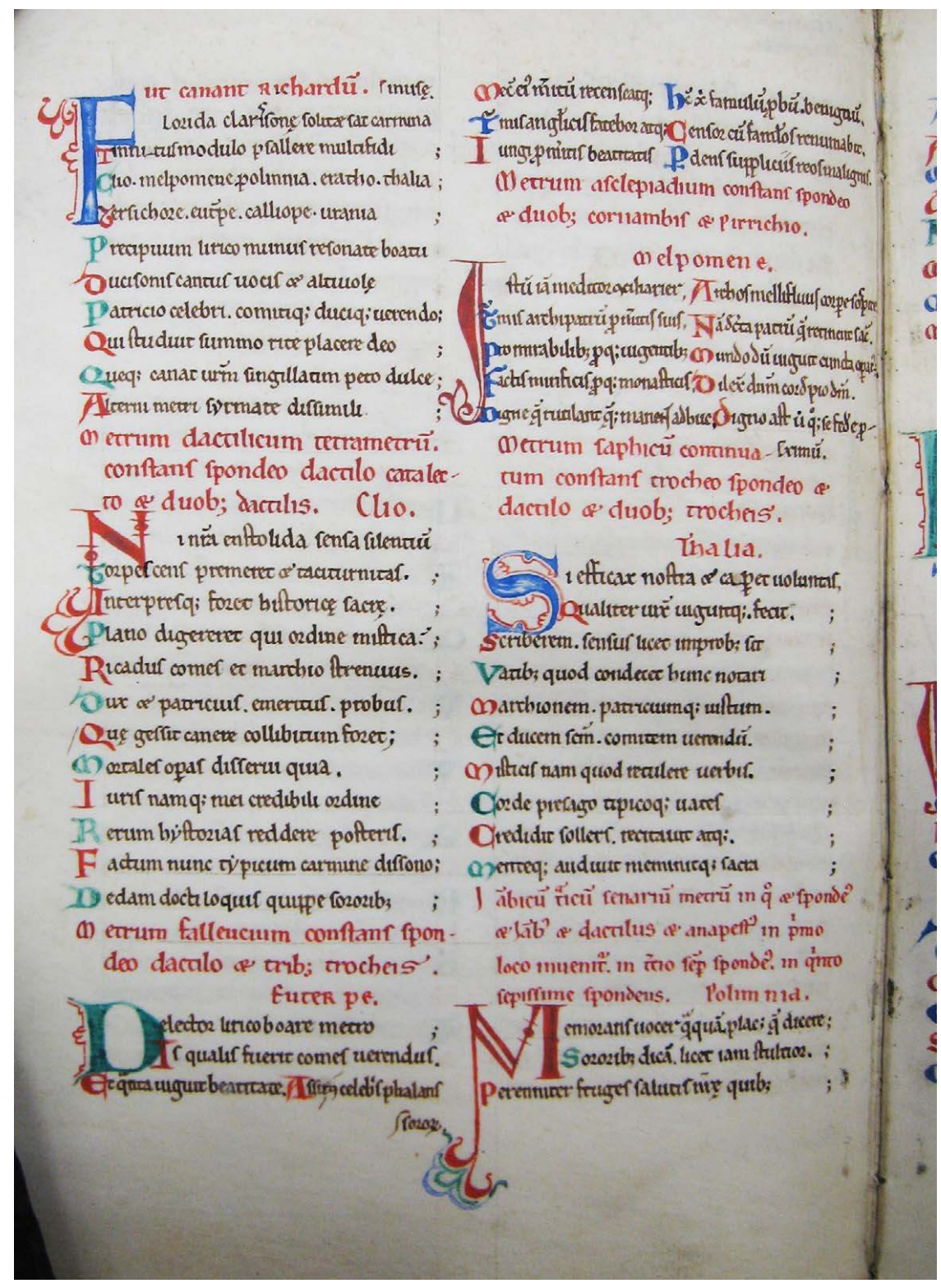

Fig. 8: Antwerp, Museum Plantin-Moretus/Prentenkabinet, ms 17.2, fol. 42v. Reproduced by kind permission of the Museum Plantin-Moretus/Prentenkabinet, UNESCO - World Heritage, Antwerp 


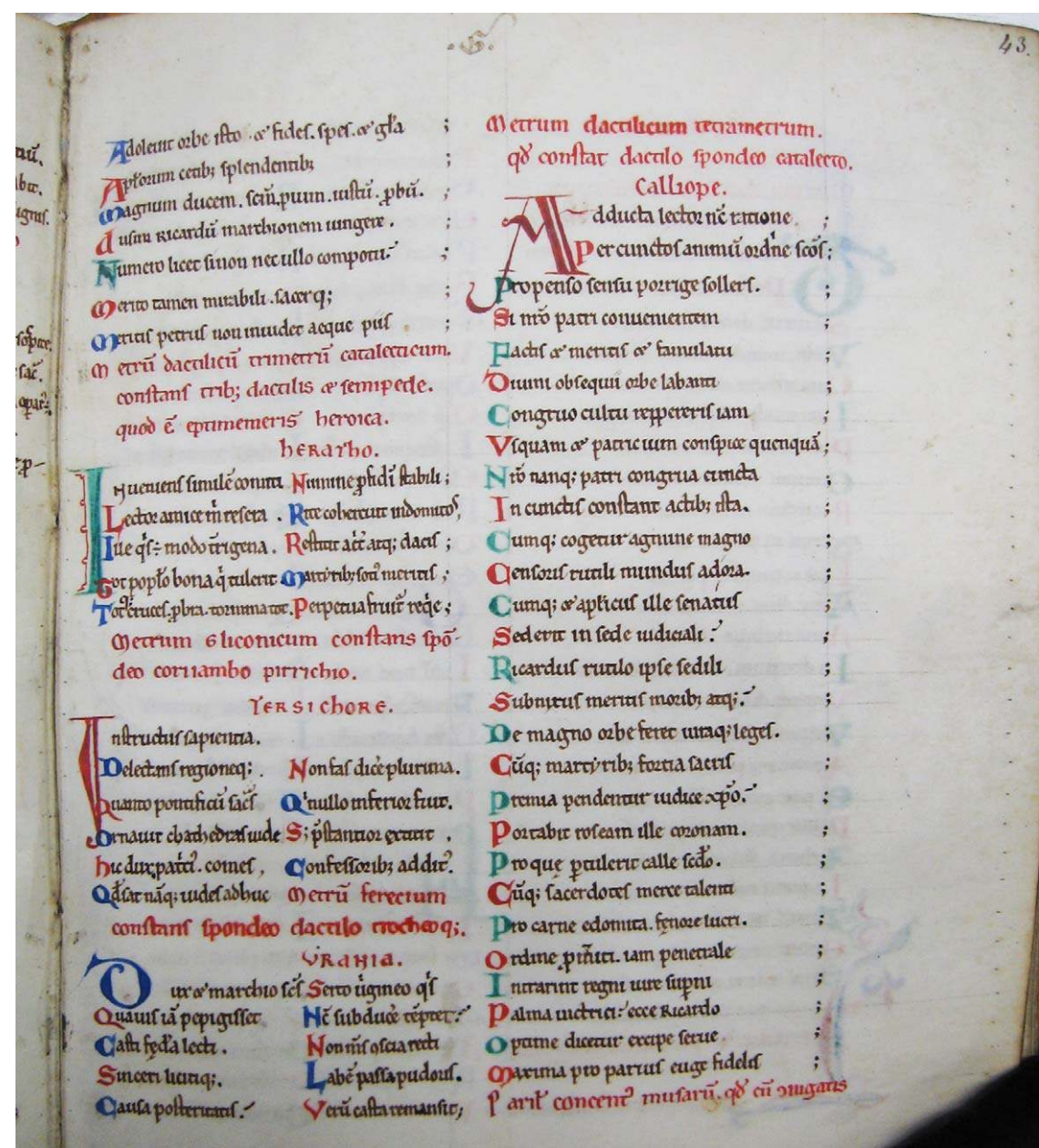

Fig. 9: Antwerp, Museum Plantin-Moretus/Prentenkabinet, ms 17.2, fol. 43r. Reproduced by kind permission of the Museum Plantin-Moretus/Prentenkabinet, UNESCO - World Heritage, Antwerp 


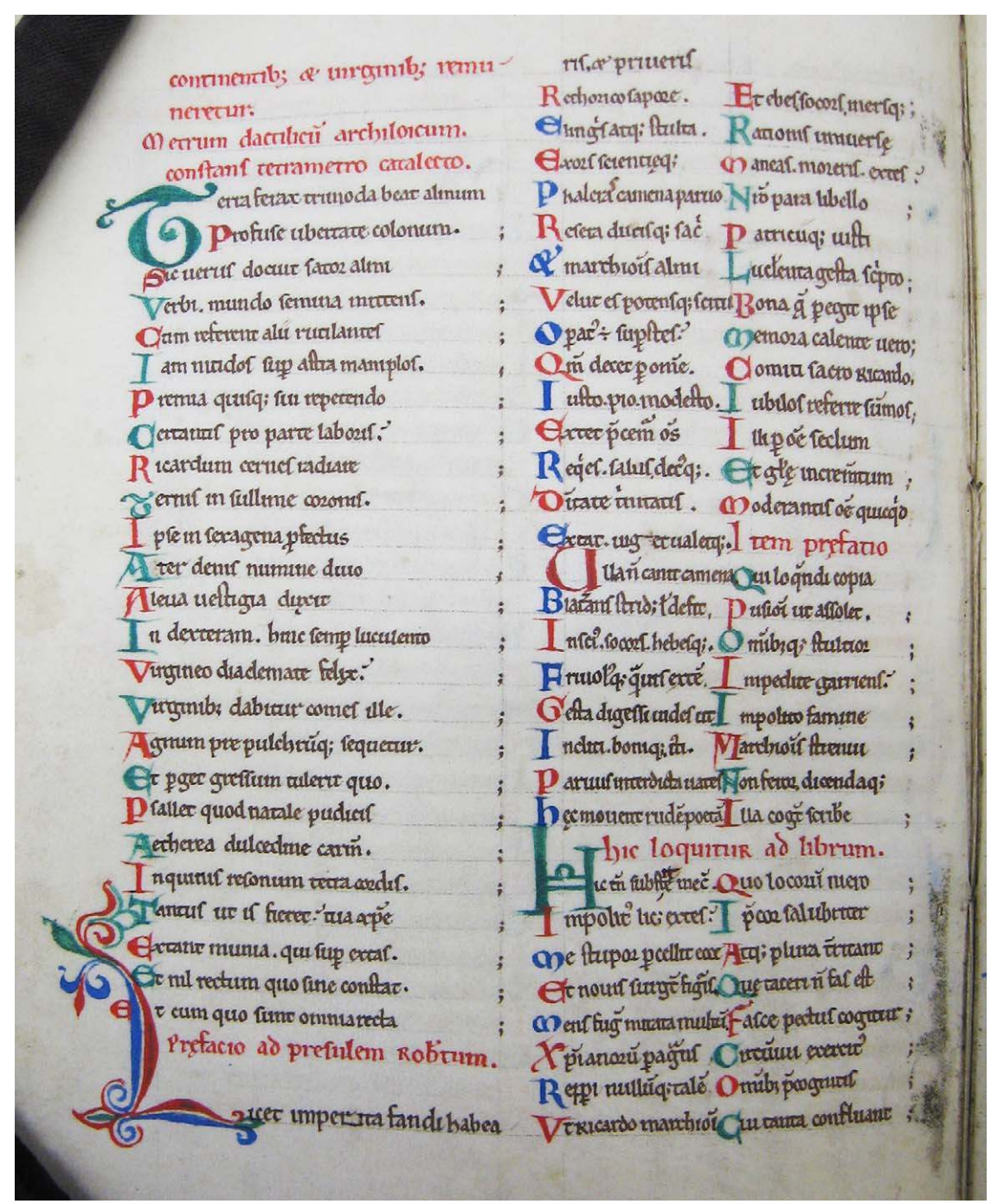

Fig. 10: Antwerp, Museum Plantin-Moretus/Prentenkabinet, ms 17.2, fol. 43v. Reproduced by kind permission of the Museum Plantin-Moretus/Prentenkabinet, UNESCO - World Heritage, Antwerp 


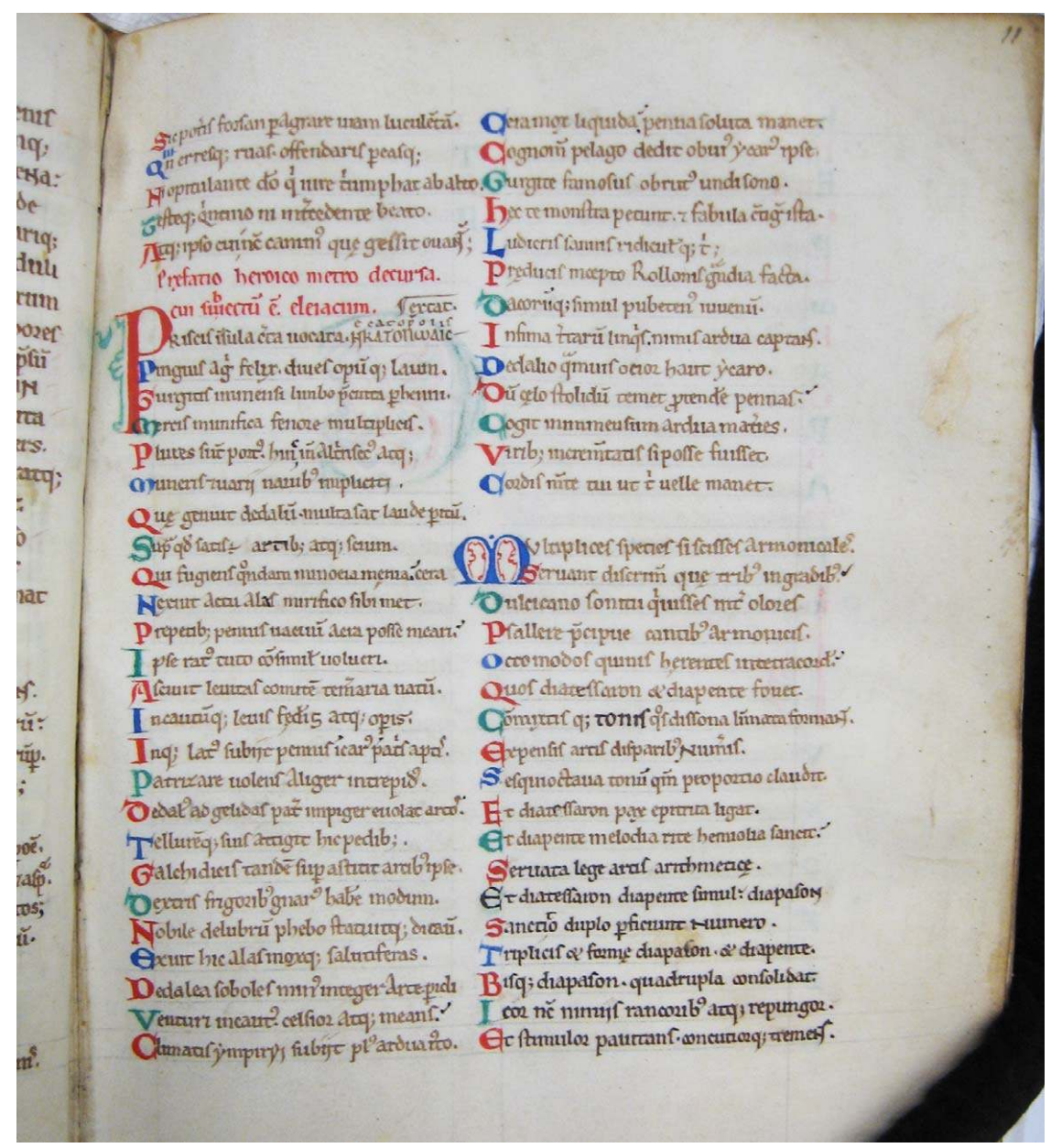

Fig. 11: Antwerp, Museum Plantin-Moretus/Prentenkabinet, ms 17.2, fol. 11r. Reproduced by kind permission of the Museum Plantin-Moretus/Prentenkabinet, UNESCO - World Heritage, Antwerp 